\title{
REACTIVE OXYGEN AND NITROGEN SPECIES IN PULMONARY HYPERTENSION
}

\author{
Diana M. Tabima, $\mathbf{P h D}^{1}$, Sheila Frizzell, BA ${ }^{1}$, and Mark T. Gladwin, MD $^{1,2}$ \\ ${ }^{1}$ Vascular Medicine Institute, University of Pittsburgh, Pittsburgh, PA, 15213 \\ ${ }^{2}$ Department of Medicine, Division of Pulmonary, Allergy and Critical Care Medicine, University of \\ Pittsburgh School of Medicine, Pittsburgh, PA, 15213
}

\section{Abstract}

Pulmonary vascular disease can be defined as either a disease affecting the pulmonary capillaries and pulmonary arterioles, termed pulmonary arterial hypertension, or as a disease affecting the left ventricle, called pulmonary venous hypertension. Pulmonary arterial hypertension (PAH) is a disorder of the pulmonary circulation characterized by endothelial dysfunction, as well as intimal and smooth muscle proliferation. Progressive increases in pulmonary vascular resistance and pressure impair the performance of the right ventricle, resulting in declining cardiac output, reduced exercise capacity, right heart failure, and ultimately death. While the primary and heritable forms of the disease are thought to affect over 5,000 patients in the U.S., the disease can occur secondary to congenital heart disease, most advanced lung diseases, and many systemic diseases. Multiple studies implicate oxidative stress in the development of PAH. Further, this oxidative stress has been shown to be associated with alterations in reactive oxygen species (ROS), reactive nitrogen species (RNS) and nitric oxide (NO) signaling pathways, whereby bioavailable NO is decreased and ROS and RNS production are increased. Many canonical ROS and NO signaling pathways are simultaneously disrupted in $\mathrm{PAH}$, with increased expression of nicotinamide adenine dinucleotide phosphate (NADPH) oxidases and xanthine oxidoreductase, uncoupling of endothelial NO synthase (eNOS), and reduction in mitochondrial number, as well as impaired mitochondrial function. Upstream dysregulation of ROS/NO redox homeostasis impairs vascular tone and contributes to the pathological activation of anti-apoptotic and mitogenic pathways, leading to cell proliferation and obliteration of the vasculature. This manuscript will review the available data regarding the role of oxidative and nitrosative stress and endothelial dysfunction in the pathophysiology of pulmonary hypertension, and provide a description of targeted therapies for this disease.

\section{Introduction: Pulmonary arterial hypertension}

Pulmonary hypertension $(\mathrm{PH})$ is broadly defined by a mean pulmonary artery pressure at rest greater than or equal to $25 \mathrm{mmHg}$ and includes a family of diseases. One form of pulmonary hypertension is the classic pulmonary arterial hypertension (PAH). PAH indicates that the disease predominantly affects the pulmonary capillaries or arterioles, a characteristic that requires hemodynamic evidence that the pressure in the pulmonary artery

\footnotetext{
(c) 2012 Elsevier Inc. All rights reserved.

Address correspondence to: Dr. Mark T. Gladwin, Pulmonary, Allergy and Critical Care Medicine, University of Pittsburgh, Phone: 412-692-2210; Fax: 412-692-2260; gladwinmt@upmc.edu.

Publisher's Disclaimer: This is a PDF file of an unedited manuscript that has been accepted for publication. As a service to our customers we are providing this early version of the manuscript. The manuscript will undergo copyediting, typesetting, and review of the resulting proof before it is published in its final citable form. Please note that during the production process errors may be discovered which could affect the content, and all legal disclaimers that apply to the journal pertain.
} 
is increased at the pre-capillary arteriolar level. Elevated pulmonary pressure results from a decrease in arterial lumen through a combination of: a) endothelial dysfunction and increased contractility of small pulmonary arteries, b) proliferation and remodeling of endothelial and smooth muscle cells, and c) in situ thrombosis. To diagnose this condition, a procedure called a right heart catheterization is required. Measurements are made by placing a balloon tipped catheter in the pulmonary artery, advancing to the small pulmonary arteries were the balloon "wedges" in the arterioles, thereby allowing for selective measurement of the back pressure coming from the pulmonary veins and left atrium (Figure 1). If this pulmonary artery occlusion pressure is less than $15 \mathrm{mmHg}$ and the pulmonary artery mean pressure is greater than or equal to $25 \mathrm{mmHg}$, PAH may be diagnosed. If, on the other hand, the pulmonary artery occlusion pressure is higher than $15 \mathrm{mmHg}$, the diagnosis is pulmonary venous hypertension, suggesting that the high pressure originates from elevations in the left atrial pressure, not from disease of the pulmonary arterioles.

The normal pulmonary vasculature is a low resistance, high flow system. In the case of $\mathrm{PAH}$, the pulmonary arterioles are progressively occluded such that the pulmonary vascular resistance and pulmonary pressures increase, ultimately leading to a drop in cardiac output as the right heart fails in the face of increasing afterload. Progressive reduction in cardiac output results in exercise intolerance, shortness of breath, fluid retention, and likely death from right heart failure. The relationship between vascular obliteration, vascular resistance, pulmonary pressures, and cardiac output (flow) can be related to Ohm's law and reviewed in Figure 2. Patients at the highest risk of death are those with evidence of progressive right heart failure, elevated right atrial pressures, low cardiac outputs, and episodes of systemic hypoperfusion or syncope (sudden loss of consciousness). "Sudden death" can occur with a profound failure of the right ventricle resulting in loss of blood flow to the brain followed by cardiac asystole.

Recently, the Dana Point working group published an expert consensus document on pulmonary hypertension, detailing the classification, epidemiology, natural history, survival, pathology, pathogenesis, and strategies for diagnosis and treatment [1]. The classification of diseases that cause pulmonary hypertension are summarized in Table 1 and include: 1) idiopathic disease where the cause is unknown (which accounts for approximately $50 \%$ of the cases of PAH [2] and occurs with a female/male ratio of 1.7:1 [3]); 2) familial disease related to hereditable germ-line mutations in three genes encoding transforming growth factor $\beta$ (TGF- $\beta$ ) receptor superfamily, namely endoglin 1 , the activin-receptor-like kinase- 1 (alk 1), and the bone morphogenic receptor (BMPR); 3) disease induced by drugs and toxins; 4) disease associated pulmonary arterial hypertension, such as that associated with connective tissue diseases, human immunodeficiency virus, portal hypertension, and congenital heart diseases; 5) persistent pulmonary hypertension of the newborn and 6) disease secondary to veno-occlusive disease.

The different forms of PAH share many pathobiological features. For example, familial or hereditable PAH, which is responsible for up to $6 \%$ to $10 \%$ of the cases of PAH [2,3], can occur based on inherited mutations in the TGF- $\beta$ receptor pathway. This is inherited via autosomal dominant transmission with incomplete penetrance and genetic anticipation. It is likely that endothelial and smooth muscle proliferation occur from changes in TGF- $\beta$ signaling prior to any observable elevations in pressure or changes in pulmonary blood flow [4]. Both hereditable PAH and idiopathic PAH are characterized by an overabundance of vascular smooth muscle in small peripheral arteries, such that the lumens are nearly occluded, resulting in increased pulmonary vascular resistance and right ventricular overload [5]. 
There are other pathologies in which pulmonary hypertension presents as a secondary disease. Some examples include: left heart disease, which is referred to as pulmonary venous hypertension (Class II, Table 1), chronic lung diseases and/or hypoxemia (Class III, Table 1), chronic thromboembolic disease (Class IV, Table 1), or pulmonary hypertension related to other miscellaneous diseases (Class V, Table 1) (e.g., lymphangiomatosis, histiocytosis X and sarcoidosis).

In all forms of PH the progressive vasculopathy is complex with a broad imbalance of vasodilative and vasoconstrictive mediators, likely preceding the development of secondary aberrant cellular proliferation. Classic vasodilator systems are dysregulated with decreases in endothelial NO synthase function (eNOS) and enzymatic "uncoupling", decreases in production of prostacyclin (cyclooxygenase-2 dysfunction), and increased expression and activity of the vasoconstrictor and mitogenic endothelin-1 signaling system [6-8]. An understanding of the critical imbalances of these three major pathways, NO, prostacyclin, and endothelin-1, has led to the rapid clinical development of three new major FDA approved medications for the therapy of $\mathrm{PAH}$, all targeting these important pathways (See Table 2). While these drugs are considered 'selective' pulmonary vasodilators, they do have effects on the systemic circulation and can produce systemic hypotension, as well as adversely affect ventilation and perfusion matching and oxygenation [9-12].

\section{Dysregulation of ROS and RNS signaling}

In addition to imbalances in NO, prostacyclin, and endothelin-1, it is increasingly apparent that enhanced production and dysregulation of ROS/RNS signaling underlies PAH pathogenesis. These pathways regulate vascular force and tone, cellular proliferation, apoptosis and modulate upstream pathological progression of PAH. A potential role of ROS and RNS in the development of pulmonary hypertension is supported by experimental data showing that several antioxidants prevent some alterations triggered by chronic hypoxia [13-15]. Moreover, it has been shown that diminished pulmonary vasorelaxation to exogenous NO is related to increased levels of ROS [16-18]. Direct scavenging of NO by superoxide can reduce NO levels and drive protein oxidation by secondary generation of peroxynitrite and nitrogen dioxide. Increased superoxide and increased Rho kinase activity can also reduce both synthesis and bioactivity of endothelium-derived NO [19, 20], thereby increasing vasoconstriction related to the development of pulmonary hypertension.

Accumulating evidence indicates that oxidase systems, such as NADPH oxidase (Nox) and xanthine oxidoreductase, are involved in changes of the pulmonary vasculature during $\mathrm{PH}$, specifically in the long-term responses of the pulmonary vasculature to hypoxia. For example, the phagocytic "respiratory burst oxidase", Nox2, plays an important role in hypoxia-induced endothelial NO-dependent dysfunction in pulmonary arteries, which results in reduced activation of soluble guanylate cyclase (sGC) or cyclic guanosine monophosphate (cGMP)-dependent protein kinase activity following chronic hypoxia [21, 22]. Increased expression of NADPH oxidase isoform 4 (Nox4) in the vasculature of patients with PAH may disrupt canonical NO signaling through a number of pathways [23]. Increased oxidative stress from Nox4 can critically alter the balance of NADP+:NADPH and tetrahydrobiopterin to dihydrobiopterin $\left(\mathrm{BH}_{4}: \mathrm{BH}_{2}\right)$, which are both necessary to maintain eNOS in a NO producing "coupled" state. In pulmonary artery adventitial fibroblasts exposed to hypoxia, a significant upregulation of Nox4 expression at the mRNA and protein levels has been described, whereas silencing of Nox4 expression by siRNA reduces ROS levels and decreases cellular proliferation [24]. In a murine hypoxia-induced model of PAH, the development of the disease has been linked to increases in Nox4 expression in vascular smooth muscle cells [25]. Similarly, in hypoxic human pulmonary 
smooth muscle cells, an increase in Nox4 expression has been reported [26] and TGF- $\beta$ induced Nox4 expression and ROS production have been linked to proliferation [26, 27].

In this review we will provide an overview of some of the functions of NO, ROS, RNS, their signaling pathways, and the relationships between them, as well as how they contribute to pulmonary endothelial dysfunction and pathological proliferative remodeling in pulmonary hypertension. We also review new therapeutic approaches targeting these pathways. Throughout this review we will refer to pulmonary hypertension as PH in the context of preclinical animal models as well as Class II-V disease. We will refer to pulmonary arterial hypertension as PAH, which will specifically indicate Class I human disease (Table 1).

\section{Pulmonary hypertension and endothelial dysfunction: Dysregulation of NO and endothelin-1 signaling}

Despite a multitude of inciting factors, the final common outcome in PAH is the elevation of pulmonary vascular resistance mediated by vasoconstriction and obstructive cellular proliferation of the pulmonary vasculature. Through the synthesis and release of vasoactive factors, the endothelium plays a critical role in maintaining the delicate and precise balance between vasoconstrictor (endothelin-1, thromboxane $\mathrm{A}_{2}$ ) and vasodilator (prostaglandin $\mathrm{I}_{2}$, NO) molecules. In PAH, endothelial damage and dysfunction change this homeostasis, altering the balance to favor vasoconstriction. An increasing number of studies suggest that dysfunction in the NO-related signaling pathway represents an important element in the pathological remodeling of the pulmonary vasculature during the development of PAH [28, 29]. One of the early events in the pathogenesis of $\mathrm{PAH}$ is impaired endothelium-dependent vasodilation, as evidenced by a lack of vasodilator response to acetycholine, bradykinin or calcium ionophore [30]. Increased superoxide production in the vessel wall and the subsequent decrease in NO bioavailability also characterize endothelial dysfunction [31-33].

\section{NO in PAH}

NO, an endothelium-derived relaxing factor; is an important signaling molecule involved in the regulation of basal vasomotor tone, blood pressure, and inhibition of vascular cell growth. NO acts by binding to soluble guanylate cyclase which in turn converts guanosine triphosphate (GTP) to cGMP, which then activates downstream cGMP-dependent protein kinases [34-36]. Another important vasoregulatory property of NO includes regulation of vascular smooth muscle proliferation and migration [37, 38].

While the protein expression level of one member of the nitric oxide synthases (NOS), endothelial NO synthase (eNOS), has been ambiguously reported as up-regulated or downregulated in patients with PAH and in animal models of PAH [39-42], there is general consensus that the NO signaling is impaired. Numerous studies have implicated decreased bioavailability of NO and/or decreased responsiveness to NO during PAH [43-45]. Furthermore, it has been shown that this decrease in bioavailability may occur secondary to impaired formation or increased consumption [46-48]. In this section we attempt to summarize the current status of $\mathrm{NO}$ signaling in $\mathrm{PAH}$, which is thought to be related to multiple signaling mechanisms, including: a) reduction, dysfunction, or uncoupling of eNOS, b) downstream effects on NO-cGMP signaling, c) catabolism of NO by ROS or hemoglobin. Finally, we describe the use of NO and agents that augment NO signaling as they relate to specific PAH therapies in clinical and experimental models.

\section{Sources of NO}

NO is primarily formed in the metabolism of L-arginine by a family of enzymes known as oxide NOS, or through a NOS-independent mechanism from the anion nitrite $\left(\mathrm{NO}_{2}^{-}\right)[49-$ 
52]. There are 3 isoforms of the enzyme: inducible NO synthase (iNOS), endothelial NO synthase (eNOS), and neuronal NO synthase (nNOS), all of which are expressed in the lung. These enzymes utilize the substrate L-arginine, molecular oxygen, and NADPH to produce L-citrulline and NO. Perhaps the most important enzyme in regulating NO production in the endothelium is the isoform eNOS. In animal models, studies have reported increased eNOS expression associated with PAH [39, 53]. Other animal studies suggest that chronic $\mathrm{PH}$ increases lung eNOS mRNA and protein expression, and total lung NOS activity. However, data from human lung tissue studies have shown a lack of consistent results. For example, Xue et al. found an increase in eNOS immunostaining [40], Giaid and Saleh found a decrease in eNOS [41] and Tuder et al. reported unaltered levels compared to healthy pulmonary arteries [42]. Some of the conflicting results within both animal models and human tissue studies may be due to the differences in time points being sampled. In the case of animal models, the NOS proteins are measured during the progression of the disease, whereas human tissues are harvested very late in the progression of the disease or even postmortem. Another important point is that the animal models of PAH do not develop the classic plexiform vascular lesions, which are characteristic of the human disease.

Some studies have also demonstrated increased iNOS in the microvasculature of a rat monocrotaline model of PAH [54]. However, further studies of the role of iNOS in PAH are needed and are beyond the scope of this review.

\section{eNOS uncoupling}

While the levels of eNOS in lung appear to vary, a functional reduction in NO signaling has been consistently reported in pre-clinical models and in patients with PAH. Reduced NO formation, measured through NO enzymatic synthesis and its rate of consumption, has been found in patients with primary $\mathrm{PH}$ [55] and in the hypoxic rat model of PH. This decreased NO production leads to reduced vasodilation in the setting of normal or increased eNOS protein levels [56]. It is now increasingly appreciated that this paradox of normal or increased eNOS expression and diminished NO signaling is potentially explained by a process termed "eNOS uncoupling," a dysfunctional state of the enzyme in which electrons transferring from the NOS reductase domain to the oxygenase domain are diverted to molecular oxygen rather than to L-arginine [57], forming superoxide rather than NO. eNOS normally forms homodimers, with each monomer containing an oxygenase domain in the $\mathrm{N}$ terminal that is comprised of binding sites for $\mathrm{BH}_{4}$, heme iron and $\mathrm{L}$-arginine. (Figure 3, for more detailed recent review, see ref [6]). Uncoupling of eNOS is associated with changes in the quaternary structure of the enzyme, which is experimentally observed as a reduction in enzyme homodimer assembly and increase in the monomer.

eNOS uncoupling can be triggered in vitro through depletion of the co-factors, L-arginine and $\mathrm{BH}_{4}$ [58]. Recent studies suggest that oxidation of tetrahydrobiopterin co-factor to dihydrobiopterin, measured as decreases in the ratio of $\mathrm{BH}_{4}: \mathrm{BH}_{2}$, or perhaps more importantly, increases in $\mathrm{BH}_{2}$, are central to enzyme coupling [59]. The eNOS enzyme generates superoxide when $\mathrm{BH}_{4}$ levels decline or when it is replaced by the oxidized $\mathrm{BH}_{2}$ $[45,60]$. Mice that have very low levels of $\mathrm{BH}_{4}$, or decreased $\mathrm{BH}_{4}: \mathrm{BH}_{2}$ ratios, exhibit $\mathrm{PH}$ [45]. Using an experimental animal model of hypoxia-induced $\mathrm{PH}$, it was reported that the oxidized form, $\mathrm{BH}_{2}$, is increased in the lungs [32].

As further evidence that eNOS uncoupling may participate in the pathogenesis of $\mathrm{PH}$, administration of $\mathrm{BH}_{4}$ has been reported to decrease pulmonary artery pressure and reduce muscularization of distal pulmonary arteries in rats with monocrotaline-induced PH [61]. 6acetyl-7,7-dimethyl-7,8-dihydropterin, a $\mathrm{BH}_{4}$ analogue, has been shown to improve NOmediated pulmonary artery dilation and enhanced expression of eNOS in the vascular 
pulmonary endothelium in an in vivo rat model of hypoxia-induced $\mathrm{PH}$ [58]. This topic has been recently reviewed in more detail [6].

A role for eNOS uncoupling has been proposed as a mechanism for the development of PH observed in the Caveolin-1 (Cav1) knock-out mouse. Caveolin-1 plays an essential role in binding eNOS in the caveoli and limiting its activity [62, 63]. Dissociation of Cav1 from eNOS thus plays a regulatory role in NO signaling by promoting it activation and allowing eNOS protein movement to the cytosol. The paradoxical finding that Cav1 knock out mice develop PH appears to be related to the release and activation of an uncoupled eNOS that produces superoxide [33, 64, 65]. Indeed, eNOS inhibition using L-NAME reverses PH development in the Cav1 mouse [66], and re-expression of Cav1 can rescue the PH phenotype in the knock-out [67]. Furthermore, treatment of neonatal Cav1 knockout mice with $\mathrm{BH}_{4}$ prevents $\mathrm{PH}$ [66]. However, in other studies, eNOS uncoupling alone did not cause PH. For example mice overexpressing eNOS in the endothelium are protected from developing hypoxia-induced PH [68], even though these mice exhibited eNOS uncoupling [69].

More recently, investigators have generated Cav1 and eNOS double knock-out mice and demonstrated the essential role of eNOS-dependent peroxynitrite formation ( $\mathrm{NO}$ and $\mathrm{O}_{2}{ }^{-}$ reactions) in the mechanism of $\mathrm{PH}$ in $\mathrm{Cav}^{-/-}$mice. In these studies the downstream formation of peroxynitrite from $\mathrm{NO}$ and superoxide reactions resulted in nitration and loss of function of protein kinase $\mathrm{G}(\mathrm{PKG})$ and the development of PH [70]. These studies appear to support the hypothesis that in a setting of increased superoxide generation, from either uncoupled eNOS or other oxidases, NO formation may increase peroxynitrite formation and drive pulmonary vasculopathy.

An additional mechanism for eNOS dysfunction that could have relevance during the development of PAH, is eNOS S-glutathionylation. This reversible protein modification could explain effects of oxidative stress on eNOS activity [71]. An association between eNOS S-glutathionylation and endothelial dysfunction has been observed [72].

\section{Dysfunction of the NO signaling pathway down-stream from eNOS}

Downstream NO signaling events may also be impaired in PAH. Murine studies have suggested that increased superoxide generation may further limit NO bioactivity [73]. In addition, altered levels of one or both sGC units ( $a 1$ and $\beta 1)$ as well as reduced NOdependent sGC activity results in a decreased generation of cGMP and reduced vascular relaxation to NO stimulation [74, 75] (Figure 4 shows a possible interplay of eNOS uncoupling and sGC). The mechanisms for altered sGC expression or activity in PAH are not entirely clear. An upregulation of sGC in pulmonary arterial smooth muscle cells from PAH patient lungs has been shown [76]. Changes in sGC expression seem to be linked but not exclusively to oxidative stress [77].

Several studies have shown an increase in cGMP-specific phosphodiesterase type 5 activity in pulmonary hypertensive animals $[78,79]$; suggesting that rapid cGMP hydrolysis may limit cGMP-dependent pulmonary vasodilation [74]. In summary, it seems that chronic PAH disrupts NO-cGMP signaling by decreasing eNOS expression or activity, increasing NO catabolism, reducing $\mathrm{sGC}$ responsiveness, and increasing phosphodiesterase type 5 activity.

\section{Hemolysis- associated pulmonary hypertension}

Patients with chronic hereditary or acquired hemolytic anemias, such as sickle cell disease, thalassemia intermedia, paroxysmal nocturnal hemoglobininuria, and other hemoglobinopathies or red cell membranopathies, develop PH as they age [80, 81]. A 
central mechanism underlying this disease progression is the process of intravascular hemolysis, which releases red blood cell hemoglobin into plasma. Cell-free plasma hemoglobin reacts with and catabolizes NO at a very high rate; more than 1000x faster than hemoglobin within the red blood cell. This reaction oxidizes NO to nitrate and inhibits its ability to vasodilate $[82,83]$. In addition to the release of hemoglobin, hemolysis releases red cell arginase 1, an enzyme that metabolizes L-arginine to ornithine, reducing its availability for de novo $\mathrm{NO}$ synthesis [83, 84]. It is also likely that hemolysis activates vascular oxidases, such as xanthine oxidase and NADPH oxidases, and hemolysis has been shown to drive eNOS uncoupling [43] (see Figure 5). These sources of ROS further reduce NO bioavailability at the endothelial and smooth muscle level. This process has been termed hemolysis-mediated endothelial dysfunction and leads to hemolysis-associated PH.

\section{Therapies using NO or NO generating drugs NO gas}

Inhaled NO is currently utilized as an effective adjuvant therapy that improves gas exchange in newborns with severe PH [85]. However, its usefulness as a therapeutic treatment for other forms of PH is currently limited [86]. In both animal and human studies, inhaled NO (5-80 ppm) induces rapid and selective pulmonary vasodilation [87-90], but its therapeutic value is limited by the dose and duration of exposure. Several concerns regarding the safety of inhaled NO remain, with one of the most important issues being the safety of NO withdrawal. Several studies have noted a potentially life-threatening increase in pulmonary vascular resistance on acute withdrawal of inhaled NO [47, 91-93]. This kind of "rebound pulmonary hypertension" is manifested by an increase in pulmonary vascular resistance, compromised cardiac output, and severe hypoxemia. Exogenous NO exposure inhibits endogenous eNOS activity [48], suggesting that a transient decrease in endogenous eNOS activity during inhaled NO therapy may be a mechanism for rebound pulmonary hypertension. It has been shown that co-administration of a phosphodiesterase 5 inhibitor (sildenafil) in children ameliorates this rebound effect [94], suggesting that inhaled NO may prove useful in the current era where many patients are taking oral sildenafil or other phosphodiesterase 5 inhibitors (see below). New delivery systems that allow for pulsed NO delivery combined with pulsed oxygen from liquid oxygen sources may allow for small portable devices of inhaled NO. Large clinical trials of inhaled NO in patients with PAH on background phosphodiesterase 5 inhibitor therapies are required to address these questions.

\section{NO donors}

Administration of organic nitrates, such as nitroglycerin, stimulates vasodilation, although development of nitrate tolerance shortly after treatment limits their usefulness. The underlying mechanisms of action are unclear and are likely to be multi-factorial [95]. Munzel and colleagues demonstrated an increase in vascular superoxide production after nitroglycerin treatment [96]. Furthermore, tolerance was prevented by co-treatment with superoxide dismutase (SOD), highlighting the role of ROS in this inhibition [96]. A later study identified a membrane-bound nicotinamide adenine dinucleotide dehydrogenase (NADH) oxidase as a likely source of superoxide production [97], and more recent studies demonstrated a role for endothelin-1 in the pathway [98]. It is likely that the increase in superoxide inactivates the NO released from nitroglycerin, increasing the formation of peroxynitrite. This may further promote supersensitivity to vasoconstrictors secondary to a tonic activation of protein kinase $\mathrm{C}$, resulting in nitrate tolerance [99]. The proposed superoxide sources are NADPH oxidase, uncoupled eNOS, and mitochondria. Superoxide and NO rapidly form peroxynitrite, which aggravates tolerance by promoting NO synthase uncoupling and inhibition of sGC and prostacyclin synthase [95]. In the case of mitochondria, recent work has defined a new tolerance mechanism through the inhibition of 
mitochondrial aldehyde dehydrogenase, which is the enzyme that bioactivates nitroglycerin [100].

\section{Nitrite}

While nitrite has historically been considered an inert oxidation product of $\mathrm{NO}$ and oxygen, increasing evidence over the last ten years has supported a role for this molecule as a potent physiological vasodilator [52,101-104]. Nitrite is reduced to NO by a variety of enzyme systems as oxygen tension drops and intracellular $\mathrm{pH}$ decreases along the physiological and pathological hypoxic gradient (Figure 6). Enzymes that have been identified with nitrite reductase activity include hemoglobin, myoglobin, neuroglobin, eNOS, xanthine oxidoreductase, and acidic disproportionation [105-112]. Nitrite has been proposed as a therapy for PH based on inhaled studies in newborn sheep with hypoxia- and thromboxaneinduced PH [51]. Recent studies show that inhaled, low-dose nebulized sodium nitrite can prevent and reverse experimental PAH and heart failure in the chronic hypoxia mouse model and monocrotaline rat model [113]. Zuckerbraun and colleagues showed that a low dose of sodium nitrite has a potent antiproliferative effect that is dependent on nitrite reduction by the enzyme xanthine oxidoreductase [113]. Nitrite in this context signals through cGMP to increase the levels of the cell cycle checkpoint inhibitor P21. Animal toxicology studies and phase Ia and Ib human studies have been completed with plans for a proof of concept phase II study over the next two years. However, further characterization of the dosing, toxicity, and mechanism of action are required.

\section{Therapies that increase cGMP levels}

\section{Phosphodiesterase inhibitors}

Selective inhibitors of the cGMP-specific phosphodiesterase type 5 enzyme, such as sildenafil and tadalafil, have shown clear efficacy in the treatment of PAH. The blockade of the phosphodiesterase type 5 enzyme prevents the normal hydrolysis of cGMP thus increasing the effects of NO, such as pulmonary vasodilation and inhibition of smooth muscle cell growth [114]. In a murine model of hemolysis-mediated PAH [44], where enhanced platelet activation and aggregation are associated with reduced vascular NO bioavailability, it has been shown that treatment with sildenafil produces an inhibitory effect on platelet activation and inactivation of the coagulation pathway [43]. Sildenafil, which potentiates NO-dependent signaling, has a relatively favorable side-effect profile; the most common being headache (16\%) and skin flushing (4-8\%). Sildenafil has been shown to improve symptoms of $\mathrm{PAH}$, such as exercise tolerance and hemodynamics, and to improve overall quality of life $[115,116]$, and is currently an FDA-approved therapy for PAH.

Another phosphodiesterase inhibitor approved by the FDA is tadalafil. An initial report in 2004 by Palmieri et al showed improvements in hemodynamics and gas exchange [117]. Later studies by Galie and colleagues reported positive effects for tadalafil alone or in combination with bosentan (PHIRST trial) [118]. The results indicated improvements in time to clinical worsening, health related quality of life, pulmonary hemodynamics, and improvements in exercise tolerance. Tadalafil has generally been well tolerated with the most common side effects being headache, myalgias, and flushing [118].

There remain several unanswered questions regarding the use of phosphodiesterase type 5 inhibitors in PAH. A major one being: whether these drugs will improve survival of patients with $\mathrm{PAH}$. Because of small sample sizes (PAH is a very rare disease, so large studies are difficult to perform), short trial duration, and the addition of second and third drugs to patients with clinical worsening, we still do not know if these drugs improve survival. 
Longer-term studies examining the durability of phosphodiesterase type 5 inhibitor benefits are still needed.

\section{sGC activators}

Because impaired signaling on the sGC-cGMP pathway has been implicated in the pathogenesis of $\mathrm{PH}$, recent efforts have focused in finding pharmacological activators and stimulators of sGC. The activators are pharmacological substances that, in a preferential manner, activate sGC in its oxidative or heme-free state but do not require NO for this activation [119], while the stimulators directly sensitize sGC to low levels of NO in the presence of a reduced (ferrous) synthetic heme [120].

BAY 58-2667 and HMR-1766 are examples of sGC activators that have been studied in animal models and in preclinical studies, producing potent selective pulmonary vasodilation (lambs) without adverse effects on pulmonary gas exchange [119]. Examples of the stimulators are BAY 41-2272 and BAY 63-2521 that stimulate sGC on an NO-independent but heme-dependent site [120,121]. Recent studies have shown that BAY41-2272 causes potent vasodilation, improves oxygenation independently of endogenous NO release, augments the response to inhaled NO, decreases blood pressure, and improves survival in hypertensive adult rats [120]. BAY 63-2521 has been shown to be as potent of a vasodilator in the pulmonary vascular bed as BAY41-2272, and both show decreases in workload of the right heart [121].

One of the sGC stimulators, Riociguat (BAY 63-2521), is currently in clinical development. A recently completed open-label (non-randomized or blinded) phase II study in patients with chronic thromboembolic PH and in patients with Class I PAH (defined in Table 1) found that this drug reduced pulmonary vascular resistance and increased the distance walked in six-minutes [122]. Side effects included hypotension, shortness of breath and headache. Larger randomized trials are currently underway.

\section{Endothelin-1}

Another important protein produced by vascular endothelial cells and important in PAH pathogenesis is endothelin-1 [123]. During PAH, an increase of endothelin-1 has been demonstrated in both plasma and lung tissue in human patient samples, as well as in animal models of PAH [124-126]. Endothelin-1 is a 21 amino acid vasoactive polypeptide that is mitogenic for vascular smooth muscle cells and stimulates the generation of other local mediators of vascular tone. The complex pulmonary vasoactive effects of endothelin-1 may include vasoconstriction as well as vasodilation, with contrasting effects determined by at least two different G-protein-coupled receptors, $\mathrm{ET}_{\mathrm{A}}$ and $\mathrm{ET}_{\mathrm{B}}$. Endothelin-1 exerts opposite effects under normal physiological conditions based on the receptor types being expressed and cellular distribution of the receptors $[127,128] . \mathrm{ET}_{\mathrm{A}}$ receptors are located predominantly on smooth muscle cells and mediate vasoconstriction, proliferation, hypertrophy, cell migration, and fibrosis [129], whereas $\mathrm{ET}_{\mathrm{B}}$ receptors are found predominantly on vascular endothelial cells where they promote vasodilation by increasing NO synthesis, prostacyclin production, and generally enhances endothelium-dependent vasodilators, which exhibit anti-proliferative properties and prevent apoptosis [130, 131]. $\mathrm{ET}_{\mathrm{B}}$ in smooth muscle generates a vasoconstrictive signal, similar to $\mathrm{ET}_{\mathrm{A}}[132,133]$. As PAH progresses, the cellular distribution of the endothelin-1 receptors changes, with decreased expression of vasodilatory endothelial $\mathrm{ET}_{\mathrm{B}}$ and increased expression of both constrictive $\mathrm{ET}_{\mathrm{A}}$ and $\mathrm{ET}_{\mathrm{B}}$ in the vascular smooth muscle cells. This observation helps explain the apparent efficacy of both selective $\mathrm{ET}_{\mathrm{A}}$ receptor blocking medications (ambrisentan, Table 2), as well as the dual $\mathrm{ET}_{\mathrm{A}}$ and $\mathrm{ET}_{\mathrm{B}}$ receptor blockers (bosentan, Table 2). 
Several studies suggest that NO and endothelin-1 regulate each other through autocrine feedback loops $[68,134,135]$. An example of this regulation is that activation of ET-1 receptors stimulates eNOS activity, whereas NO-cGMP production inhibits endothelin-1 peptide secretion and reduces $\mathrm{ET}_{\mathrm{A}}$ receptor gene expression in vascular endothelial cells $[136,137]$. In addition, it has been shown that peroxynitrite, formed in the reaction between superoxide and NO, can irreversibly inhibit eNOS activity in vitro [138] and increase levels of nitrated eNOS protein in vivo [31]. This nitration is significantly reduced by $\mathrm{ET}_{\mathrm{A}}$ receptor blockade [138]. These data suggest that endothelin-1-ET $\mathrm{A}_{\mathrm{A}}$ receptor-mediated increases in superoxide production with a resultant increase in vascular smooth muscle cell proliferation and NOS inhibition, coupled with $\mathrm{ET}_{\mathrm{A}}$ receptor-mediated vasoconstriction, may play a significant role in the development of endothelial dysfunction and $\mathrm{PH}$.

A similar feedback loop occurs between the ET-1 signaling pathway and NADPH oxidasedependent ROS formation. While endothelin- 1 activation of $\mathrm{ET}_{\mathrm{A}}$ receptors can activate NADPH oxidase-dependent ROS formation, conversely, ROS can regulate cellular levels of endothelin-1 and mediate its secretion. Endothelin-1 release is increased by human umbilical vein endothelial [139] or bovine aortic endothelial cells [140] exposed to cyclic strain, which can be blocked by pretreatment with antioxidants. Some studies also suggest a role for the transcription factor complex activator protein-1 in the ROS-mediated increase in endothelin-1 promoter activity. Interestingly, endothelin-1 has been shown to increase activator protein-1 DNA binding in rat aortic smooth muscle cells via a pathway involving ROS [140]. Furthermore, endothelin- 1 stimulates activator protein- 1 activation in rat smooth muscle cells via $\mathrm{ET}_{\mathrm{A}}$ receptor binding and ROS production [141]. This evidence suggests that abnormal regulation of endothelin-1 expression in $\mathrm{PH}$ may involve a positive feedback loop; $\mathrm{ET}_{\mathrm{A}}$ receptor-mediated increases in superoxide production from smooth muscle cells may result in increased endothelin-1 promoter activity and endothelin-1 secretion in the adjacent endothelial cells.

\section{Endothelin-1 receptor antagonists}

As discussed above, endothelin- 1 is a potent endogenous vasoconstrictor and smooth muscle cell mitogen that is overexpressed in the lungs and blood of PAH patients. Endothelin-1receptor antagonists have emerged as important therapeutics for PAH. In patients with PAH, bosentan, a combined $\mathrm{ET}_{\mathrm{A}}$ and $\mathrm{ET}_{\mathrm{B}}$ receptor agonist, decreases pulmonary vascular resistance, and pulmonary pressures, increases cardiac output, and improves exercise tolerance [142]. Significant benefits of bosentan treatment have been demonstrated in children with PAH [143], in PAH associated with human immunodeficiency virus [144], and in patients with portopulmonary hypertension [145]. However, bosentan can produce hepatotoxicity and liver enzymes must be monitored during its use.

Ambrisentan blocks only endothelin A-receptors and has also been shown to significantly improve hemodynamics and exercise capacity in PAH [142, 146, 147]. Although endothelin-1 receptor antagonists are generally well tolerated, they are associated with side effects related to their vasodilatory properties, including; peripheral edema, headache, and palpitations. The FDA black box warning for liver toxicity has recently been removed for ambrisentan based on the limited evidence for significant liver toxicity with this agent [148].

Other potential therapeutic uses for endothelin-1 receptor antagonists include pulmonary hypertension associated with congenital heart disease and persistent pulmonary hypertension of the newborn. Endothelin-1 receptor antagonists induced potent pulmonary vasodilation in a lamb model of congenital heart disease with decreased pulmonary blood flow [85]. In addition, $\mathrm{ET}_{\mathrm{A}}$ receptor blockage prevented endothelin-1 induced fetal pulmonary arterial smooth muscle cell proliferation [149]. 


\section{Oxidative stress: ROS and RNS}

Aside from their initially-described role in antimicrobial defense, ROS/RNS generation and redox signaling have emerged as normal physiological responses leading to essential cellular functions. Numerous effector responses that arise from redox signaling include cellular differentiation, proliferation, migration, apoptosis, and antioxidant gene expression. Some of the best studied signaling effectors involved in these phenotypes include the MAPKs, protein tyrosine phosphatases, NF- $\mathrm{kB}$, AP-1 and the Nrf2/keap pathways. ROS/RNS levels reported to effect such responses are generally considered to be log orders of magnitude lower than those generated by the phagocyte respiratory burst. In contrast, 'oxidative stress' has been widely used to describe the consequence of an imbalance in ROS and RNS homeostasis due to excessive formation of these species and/or to decreased antioxidant defenses. By one generally accepted measure, cellular "stress" occurs when a shift in the balance of a remarkably stable reservoir of reduced and oxidized glutathione occurs in favor of oxidation and/or when essential reducing proteins with specialized function (i.e. thioredoxin, glutaredoxin) are neutralized or depleted. This imbalance can affect cellular homeostasis either through direct oxidative and often irreversible damage of basic cellular components (proteins, lipids, and nucleic acids), leading to defective cellular function, apoptosis, tissue damage, and vasculopathy. In recent years it has become evident that ROS and RNS play a contributory role in the pathogenesis of PAH [150]. The term ROS encompasses a variety of oxygen-derived moieties with high reactivity towards other biomolecules, including both free radicals (substances containing one or more unpaired electrons, such as superoxide $\left(\mathrm{O}_{2}^{-}\right)$, hydroxyl $(\mathrm{OH} \bullet)$, peroxyl $\left(\mathrm{RO}_{2} \bullet\right)$, and hydroperoxyl $\left(\mathrm{HO}_{2}{ }^{\bullet}\right)$ radicals) and non-radical species such as hydrogen peroxide $\left(\mathrm{H}_{2} \mathrm{O}_{2}\right)$ and other peroxides $(\mathrm{ROOH})$, which are generally capable of oxidizing molecular targets. Increased markers of oxidative stress are found in human patients with $\mathrm{PH}$, as well as in various animal models of PAH [14, 32, 150-152], supporting the notion that ROS and RNS play a major role in the development and progression of $\mathrm{PH}$.

As alluded to above, ROS at the proper locations and concentrations can function as second messengers and activate multiple signal transduction pathways within the cell, facilitating the action of growth factors, cytokines, and calcium, via common or diverse upstream pathways. As an example, ROS activates protein kinase $\mathrm{C}-\varepsilon$ to regulate specific ion channels, contributing to the increase in intracellular $\mathrm{Ca}^{2+}$ and associated contraction in pulmonary artery smooth muscle cells. A positive-feedback mechanism to further enhance intracellular ROS generation has been proposed by Rathore and collaborators, whereby they find mitochondrial ROS-dependent activation of protein kinase C- $\varepsilon$ can augment Nox activity and leads to a further increase in intracellular ROS generation [153]. As a consequence, Nox activity contributes to a significant and functionally important increase in intracellular ROS and $\mathrm{Ca}^{2+}$ concentration observed in PAH. Another example is the activation of mitogen-activated protein kinase (MAPK), c-Jun N-terminal kinase (JNK) by ROS [141]. JNK is a crucial mitogen-activated protein kinase, which activates key proteins involved in the release of cytochrome $\mathrm{c}$ and other pro-death mediators in the cytosol. As further example, the addition of exogenous $\mathrm{H}_{2} \mathrm{O}_{2}$ or different pharmacologic agents (ie. Naphthoquinolinedione LY83583) that can increase ROS generation appear to stimulate the activation of MAPK and cellular growth [154-157].

The effects of ROS in cellular signaling include activation of many major cell signaling pathways such as MAPK, phosphoinositide 3-kinase (PI3K)/Akt, nuclear factor kappa-light chain-enhancer of activated $\beta$ cells (NF- $\kappa \mathrm{B}$ ), extracellular signal-regulated kinase (ERK), JNK, and protein 53 (p53). 
In chronic hypoxia, some studies have shown an increase in cellular levels of ROS, which are likely due in part to increased numbers of inflammatory cells in the lung vasculature and parenchyma $[158,159]$. These increases of ROS also stimulate platelet-derived growth factor $[157,160]$, and play an important role in signal transduction pathways of growth factors.

RNS, such as peroxynitrite $\left(\mathrm{ONOO}^{-}\right)$, have also been implicated in $\mathrm{PH}$ pathogenesis. For example, under hypoxic conditions, the downstream mediator PKG, which plays an important role in vascular relaxation [161], is inhibited by peroxynitrite mediated tyrosine nitration [162, 163]. During PH, peroxynitrite reacts strongly with numerous biologically important molecules, and can cause toxicity and death of endothelial cells and smooth muscle cells. Additionally, peroxynitrite can activate ERK [16-18], p38 MAP kinase [24], and protein kinase $\mathrm{C}[25,164]$, which are key mediators of smooth muscle cell and endothelial cell proliferation. Nitrative stress, through peroxynitrite-induced tyrosine nitration, damages eNOS and prostacyclin synthase, which impairs vasodilation by diminishing the capacity of vessels to synthesize the vasodilators $\mathrm{NO}$ and prostaglandin $\mathrm{I}_{2}$ [165]. Moreover, peroxynitrite damage to eNOS redirects the synthase activity from NO to superoxide generation (uncoupling), which, in turn, has been implicated in eNOS-dependent tyrosine nitration of prostacyclin synthase [166] and PKG [above].

In the next sections we review the sources of cellular ROS in PH and the data suggesting their important role in $\mathrm{PH}$ pathogenesis.

\section{What are the sources of ROS?}

ROS is produced by all vascular cell types; including, endothelial, smooth muscle, and adventitial fibroblasts [167-171], and can be generated from both metabolic and enzymatic sources. These sources include the mitochondrial electron-transport chain, pathways of arachidonic acid metabolism, uncoupled eNOS, xanthine oxidoreductase, the many isoforms of Nox, cyclooxygenase, and cytochrome P450. In PAH, Nox 2 and 4, xanthine oxidoreductase, uncoupled NOS and the mitochondrial electron-transport chain appear to play a major role in physiological and pathological ROS signaling $[25,172,173]$.

\section{Nox family in PAH}

The Nox family of parenchymal NADPH oxidases includes Nox1, Nox3, Nox4, Nox5, Duox 1 and Duox 2, and, the phagocyte NADPH oxidase gp91 ${ }^{\text {phox }}$, also known as Nox2. Four of these- Nox1, Nox2, Nox 4 and Nox5, are found in the vasculature of humans, whereas Nox 5 is not present in rodents. The NADPH oxidases are distinct biochemically in their regulation, expression, and activity, but retain their ability to use NADPH as the electron donor to reduce molecular oxygen to $\mathrm{O}_{2}{ }^{\bullet-}$ and/or $\mathrm{H}_{2} \mathrm{O}_{2}$. The production of $\mathrm{H}_{2} \mathrm{O}_{2}$ by Nox is still controversial and many maintain that it arises from rapid dismutation in or in close vicinity to the Nox catalytic site. Importantly, Nox are shown to be the major source for the generation of ROS in vascular smooth muscle cells [149], endothelial cells [28], and fibroblasts [171]. Accumulating evidence indicates that in the pulmonary vasculature ROS derived from Nox enzymes, in particular Nox 1 , Nox 2 and Nox4, play an important role in the impaired tone and contractile response due to hypoxia [23, 174]. A large number of growth factors and agonists of G-protein coupled receptors, such as serotonin and endothelin-1 have been shown to activate Nox. Activation of Nox by serotonin stimulates proliferation of bovine pulmonary arterial smooth muscle cells via a pathway involving the MAP kinases, ERK1/2 [175, 176]. Furthermore, endothelin-1 stimulates the proliferation of smooth muscle cells isolated from the pulmonary arteries via Nox-catalyzed ROS production [149]. 
DeMarco and colleagues $[150,177]$ recently showed that the transgenic (mRen2)27 rat, a model characterized by over-expression of mouse renin in extra-renal tissues and increased local synthesis of antiotensin II, results in angiotensin II-dependent ROS formation, pulmonary vascular remodeling, and systemic and pulmonary hypertension. Data from those studies support the concept that PH can occur as a consequence of Nox2-induced oxidative stress, mediated by upstream activation of the local renin-angiotensin system within the pulmonary vasculature and lung parenchyma $[150,177]$. Other laboratories have shown that gene therapy targeting the renin-angiotensin system reverses PH. Specifically, the use of angiotensin-converting enzyme inhibitors or angiotensin receptor reduces right ventricular systolic pressure and wall thickening of small pulmonary arteries [178-181]. The efficacy of these therapies relates to a decrease in angiotensin II-dependent Nox2 activation and resultant oxidative stress in the pulmonary vasculature and in the right ventricle.

Another model of PH that has been used to study the role of Nox is persistent PH of the newborn caused by either prenatal placement of an aortopulmonary shunt or ductal ligation [74, 182]. In this model, elevated levels of superoxide have been found in the pulmonary arterioles $[182,183]$. Superoxide has been defined as the primary oxidant causing oxidative stress and may be derived mainly from Nox and secondarily from uncoupled eNOS [74, 182-185]. In the chronic hypoxia-induced PH model, alterations in NO and ROS have been implicated as important mechanisms by which hypoxia induces pulmonary vascular dysfunction. In this model, hypoxia causes increased Nox4 expression in pulmonary artery smooth muscle cells [186], and the inhibition [25] or knock down- silencing [26] of Nox4 reverses PAH through reduction of ROS formation and smooth muscle cell proliferation. Furthermore, pathological changes in this model, such as increased mean right ventricular pressure, medial and adventitial wall thickening of small pulmonary arteries, right ventricular hypertrophy, and increased intrapulmonary generation of superoxide, are also abolished in Nox 2 knockout mice [23], suggesting a role for both Nox isoforms in this model. The Nox enzymes are not only the principal generator of $\mathrm{O}_{2}{ }^{-}$in the vasculature during PAH, but also regulate the activities of other ROS-generating oxidases such as xanthine oxidase and eNOS [151, 187], and they are important in the recruitment of ROSgenerating phagocytic cells [188]. Although the activation of intrapulmonary Nox 2 and 4 has been postulated as mediator of PAH in animal models, the extrapolation of the contribution of oxidative stress in the etiology of PAH in humans may be premature because the animal models of PAH do not completely reproduce the pathophysiology observed in the advanced stages of human PAH.

\section{Xanthine oxidoreductase}

Another critical source of intracellular ROS is xanthine oxidoreductase, which catalyzes the terminal two steps in purine degradation (hypoxanthine $\rightarrow$ xanthine $\rightarrow$ uric acid) and primarily exists in cells as a dehydrogenase where substrate-derived electrons reduce $\mathrm{NAD}^{+}$ to NADH. During inflammatory conditions, oxidation of critical cysteine residues or limited proteolysis converts xanthine oxidoreductase dehydrogenase to xanthine oxidase $[189,190]$. Xanthine oxidase transfers substrate-derived electrons to $\mathrm{O}_{2}$, generating $\mathrm{O}_{2}{ }^{-}{ }^{-}$and $\mathrm{H}_{2} \mathrm{O}_{2}$. However, it is important to note three crucial concepts: 1) conversion to xanthine oxidase is not essential for ROS production, as xanthine oxidoreductase dehydrogenase displays partial oxidase activity under conditions in which the $\mathrm{NADH} / \mathrm{NAD}^{+}$ratio is increased, such as hypoxemia $[191,192], 2)$ the major ROS product (80-95\%) of xanthine oxidoreductase under normal and pathophysiological conditions is $\mathrm{H}_{2} \mathrm{O}_{2}$ [193], and 3) hypoxia induces xanthine oxidoreductase expression and activity [194]. Therefore, when produced in or distributed to critical sites in the vasculature, xanthine oxidoreductase is a significant source of ROS that modulates vascular function. This is evidenced by reports demonstrating enhanced xanthine oxidoreductase activity in the arteries of patients with PAH [195], in 
cultured endothelial cells [196-198], and in a rodent model of PH [14]. As such, xanthine oxidoreductase can serve as a crucial locus of ROS formation driving pathological processes that drive $\mathrm{PAH}$. For example, increased vascular $\mathrm{O}_{2}{ }^{-}$production during chronic hypoxia, which has been found to adversely impact endothelial function by impairing NO signaling $[199,200]$ and to directly contribute to vascular remodeling, has been attributed in part to enhanced xanthine oxidoreductase activity [14], whereas treatment of chronic hypoxiainduced PAH rodents with xanthine oxidoreductase-specific inhibitors normalizes blood pressure $[14,151]$. However, there exists an unresolved paradox regarding the role of xanthine oxidoreductase as contributory to $\mathrm{PH}$ or as a nitrite reductase that prevents and reverses experimental PH [113]. One explanation for these discordant roles of xanthine oxidoreductase may involve the presence of nitrite, which may divert electrons from oxygen and pathological superoxide formation to nitrite and protective NO (or alternative protective nitrite oxidation reactions).

\section{Mitochondrial ROS in PAH}

Experimental evidence suggests that a small percentage of the $\mathrm{O}_{2}$ used by mitochondria is not completely reduced to water but is converted to $\mathrm{O}_{2}{ }^{-}$- because of the escape of electrons at complexes I and III of the electron transport chain [201-205]. Indeed, under physiological conditions, in endothelial and smooth muscle cells from pulmonary arteries, mitochondria produce ROS as byproducts of aerobic metabolism by the electron transport complexes, with $1-2 \%$ of oxygen converted to $\mathrm{O}_{2}{ }^{-}$at any given time [206-208]. This production can be affected by modulation of mitochondrial redox status and biogenesis, fusion and fission processes, and changes in mitochondrial bioenergetics [209]. Superoxide dismutase 2 (SOD2) converts intra-mitochondrial superoxide to diffusible $\mathrm{H}_{2} \mathrm{O}_{2}$, which directly or indirectly (via protein phosphorylation) stimulates various signaling pathways, including those involving adenosine monophosphate-activated protein (AMP) kinase (AMPK), nuclear migration of redox-sensitive transcription factors, and regulation of Kv1.512 channel activity (described in detail below). The downstream actions of $\mathrm{H}_{2} \mathrm{O}_{2}$ may play a role in the regulation of pulmonary vascular tone or by modulating cellular proliferation and apoptosis. For example, the activation of AMPK, JNK, and nuclear NF- $\kappa \mathrm{B}$ may participate in the upregulation of cytoprotective genes, including those related with glucose transporters, antiapoptotic factors, glycolysis, antioxidant defenses, and repair mechanisms $[210,211]$.

$\mathrm{H}_{2} \mathrm{O}_{2}$ has both contractile and relaxant effects depending of the anatomical portion of the pulmonary artery (extra-conduit or intralobar-resistance vessel) and vasodilatory state (basal or pre-constricted state). Under basal tone, $\mathrm{H}_{2} \mathrm{O}_{2}$ induces constriction in intrapulmonary arteries. However, in the case of the pre-constricted state, $\mathrm{H}_{2} \mathrm{O}_{2}$ causes a transient contraction followed by relaxation in the intralobular pulmonary artery [212]. Formation of $\mathrm{ONOO}^{-}$results from the reaction between $\mathrm{NO}$ and $\mathrm{O}_{2}{ }^{-}$. As we explained before, $\mathrm{ONOO}^{-}$ is a reactive molecule that may nitrate or oxidize other biological molecules. Under physiological conditions, the contribution of mitochondrial $\mathrm{O}_{2}{ }^{-}$to this process is not clear because of the high levels of SOD present in the mitochondria [209]. However, during PAH, where the systems that have the capacity to dismutate $\mathrm{O}_{2}{ }^{--}$are impaired or saturated [182, 213], the formation of $\mathrm{O}_{2}{ }^{-}$or $\mathrm{ONOO}^{-}$by the electron transport chain may be enhanced $[214,215]$.

Two major theories of mitochondrial dysfunction in PAH have been promoted. The first theory suggests that the mitochondrial electron-transport chain, which is embedded in the inner membrane of the mitochondria and is the main energy source for the cell, may become a source of ROS that promotes cellular senescence, necrosis, or apoptosis [187], leading to vasculopathy. In support of this, investigators have reported that increases in mitochondrial- 
derived ROS formation at the sites prior to the semi-ubiquinone site of complex III contribute to hypoxic pulmonary vasoconstriction [216, 217]. Additionally, changes in production of mitochondrial ROS have been observed following activation or stabilization of transcription factors with important roles in $\mathrm{PAH}$, such as the peroxisome proliferatoractivated receptor-gamma coactivator (PGC)-1a [30, 218] and hypoxia-inducible factor-1 alpha (HIF-1a) [219, 220]. Similarly, the catalase mimetic, tempol, which has the potential to scavenge cellular $\mathrm{H}_{2} \mathrm{O}_{2}$, has shown beneficial effects in PAH [221].

Alternatively, the second mitochondrial-based theory compares the metabolic theory of cancer with $\mathrm{PAH}$, whereby mitochondrial dysfunction and a reduction in physiological ROS (most likely $\mathrm{H}_{2} \mathrm{O}_{2}$ ) levels drive the pathogenesis of the disease (Figure 7). According to this model, based largely on studies in the fawn-hooded rat that develops spontaneous PH, both hypoxia and a PAH disease state result in inhibition of the mitochondrial electron-transport chain and a shift from oxidative metabolism to anaerobic glycolysis. This results in both the accumulation of reducing equivalents of NADH and $\mathrm{FADH}_{2}$ and a reduction in ROS production from the mitochondria, leading to a net decrease in cellular redox potential. This low redox state inhibits the redox-sensitive voltage-gated potassium channel Kv1.512 activity causing cellular depolarization, increasing intracellular $\mathrm{Ca}^{2+}$, and vasoconstriction of pulmonary artery smooth muscle cells [222]. Studies supporting this model show that diseased PH-pulmonary arterial smooth muscle cells exhibit morphological fragmentation, hyperpolarized mitochondrial membrane potentials, and reduced $\mathrm{H}_{2} \mathrm{O}_{2}$ production compared to healthy pulmonary arterial smooth muscle cells [223-225].

Decreases in mitochondrial $\mathrm{H}_{2} \mathrm{O}_{2}$ production may in part be mediated by SOD2 deficiency [226]. SOD2 regulates physiological production of $\mathrm{H}_{2} \mathrm{O}_{2}$ (produced from mitochondrial superoxide during respiration). $\mathrm{H}_{2} \mathrm{O}_{2}$ is less toxic than superoxide and can freely diffuse through membranes. This greater diffusion radius allows it to serve as a signaling molecule. $\mathrm{H}_{2} \mathrm{O}_{2}$ inhibits hypoxia-inducible factor-1 alpha (HIF-1a) [222, 223] and activates the sulfhydryl rich voltage-gated potassium channel Kv1.512. Therefore, a reduction in mitochondrial $\mathrm{H}_{2} \mathrm{O}_{2}$ production would be expected to activate HIF-1 dependent hypoxic signaling pathways and to inhibit Kv1.512, producing vasoconstriction and cellular proliferative responses.

Several downstream molecular changes associated with PAH, such as normoxic decreases in mitochondrial $\mathrm{H}_{2} \mathrm{O}_{2}$ production, mitochondrial pyruvate dehydrogenase kinase activation, and a shift from oxidative to glycolytic metabolism, are explained by normoxic activation of the oxygen-sensitive transcription factor HIF-1a. This drives a pseudohypoxic state, which is characterized by the use of glycolysis even in the presence of normal oxygen levels. These physiological shifts may also drive resistance to apoptosis through expression of survivin, a cell cycle-regulating protein that regulates mitochondrial function and has anti-apoptotic effects [227]. This resistance to apoptosis has been proposed as an example of the similarities between cancer cells and PAH- pulmonary arterial smooth muscle cells [227, 228].

In the case of PAH-endothelial cells, it has been shown that these cells share similar abnormalities with PAH-pulmonary arterial smooth muscle cells, including increased glycolytic rates and lower mitochondrial density compared to healthy cells [229, 230]. Similar to cancer, this is associated with the suppression of mitochondrial activity, such as glucose oxidation, resulting in a metabolic switch to glycolysis, which is associated with anti-apoptotic behavior [228, 231]. Another shared characteristic is that mitochondria found in malignancies have hyperpolarized mitochondrial membrane potential and reduced mitochondrial ROS production [232]. 
So, how do we reconcile these two competing theories, one suggesting that increases in ROS underlie $\mathrm{PH}$ pathogenesis and the other that decreases in mitochondrial ROS cause $\mathrm{PH}$ ? The answer likely lies in the enzymatic source, along with the identities and quantities of measured ROS. High levels of NADPH and xanthine oxidoreductase-derived superoxide and secondary $\mathrm{ONOO}^{-}$in the setting of hypertension and inflammation are likely pathologic, while the physiologically regulated flux of $\mathrm{H}_{2} \mathrm{O}_{2}$ by mitochondria may tonically activate the potassium channel Kv1.512 and limit intracellular calcium levels.

\section{Therapies targeting ROS and RNS signaling}

Due to the role of ROS in PAH, multiple strategies intending to diminish ROS levels have been proposed as potential therapeutic treatments for PAH. Scavengers of ROS have shown beneficial effects in animal models of PAH. Indeed, treatment with recombinant human MnSOD is able to enhance eNOS expression and function in animal models of $\mathrm{PH}$ through superoxide metabolism and restoration of $\mathrm{BH}_{4}$ levels [182]. The augmentation of MnSOD with Manganese(III)tetrakis(4-benzoic acid) porphyrin chloride, a SOD mimetic, reverses $\mathrm{PAH}$, improving exercise capacity and reducing right ventricle hypertrophy in fawn-hooded rats [222].

Another strategy has been to inhibit the ROS generating sources. Inhibition of uncoupled eNOS with L-NAME decreases ROS and reverses PAH in caveolin-1 knockout mice in which superoxide is produced by the uncoupled eNOS [65]. Studies have detected evidence that increased heme-oxygenase-1 may increase extracellular superoxide dismutase expression, decrease superoxide, and attenuate PH [213]. Use of ROS scavengers [183], inhibitors of NADPH oxidase [23, 172], $\mathrm{BH}_{4}$ [41], and statins [177, 233, 234] prevent or reverse pulmonary hypertension through normalization of the vasodilator response to exogenous NO. Furthermore, genetic deficiency in ROS-generating enzymes protects some animals from experimental PAH [23]. For example, in NADPH oxidase knockout mice the pathological changes associated with hypoxia-induced PH are completely abolished [23]. Current standard treatments of $\mathrm{PAH}$, such as phosphodiesterase type 5 inhibitors, have also been reported to lower ROS levels [235].

Therapies causing a regression of the mitochondrial abnormalities that cause the shift from oxidative to glycolytic metabolism constitute promising alternatives against PAH. As an example, dichloroacetate, an inhibitor of mitochondrial pyruvate dehydrogenase kinase, restores normal oxidative metabolism in fawn-hooded rats, a mutant strain unique in spontaneously developing PAH [236], thereby shifting them away from the proliferative/ apoptosis-resistant glycolytic state [224, 232, 237]. Another potential treatment lies in targeting the fatty acid oxidation pathway, since inhibition of this pathway indirectly promotes glucose oxidation [238]. In vivo, trimetazidine, an inhibitor of the fatty acid oxidation pathway, depolarizes the mitochondrial membrane potential and increases mitochondrial ROS without affecting systemic blood pressure in rodent models. Recent studies have evaluated PPAR gamma activation using rosiglitazone and nitrated fatty acids, reporting that this reduces Nox4 activation and prevents and reverses experimental PH [239-244]. Collectively, these data support the view that metabolic modulators may be selective for the pulmonary circulation [238]. Since fatty acid oxidation inhibitors are clinically available, more studies of their effect on PAH are needed in order to have a rapid translation to clinical trials.

\section{Summary and future directions}

Pulmonary hypertension is associated with a generalized state of reduced NO signaling and enhanced oxidative stress. Current therapies targeting endothelial dysfunction and 
vasoconstriction have shown efficacy in terms of reducing pulmonary pressures, increasing right heart function (cardiac output), and improving exercise performance. The large body of evidence indicates a role for ROS and RNS in PH, and the development of therapeutic treatments directly targeting these molecules remain promising. In this review we show that dysregulated NO signaling and oxidative stress plays a significant role in the pathogenesis of this disease. New therapeutic approaches are being developed to directly enhance NO signaling, recouple eNOS, scavenge ROS, directly inhibit Nox 2 and 4 and xanthine oxidoreductase, and restore mitochondrial function.

\section{Acknowledgments}

We would like to thank Drs. Sruti Shiva, Eric Kelley and Patrick Pagano for their critiques and constructive input. Dr. Gladwin receives research support from NIH grants RO1HL098032, RO1HL096973, RC1DK085852, PO1HL103455, the Institute for Transfusion Medicine and the Hemophilia Center of Western Pennsylvania.

\section{References}

1. New developments in pulmonary hypertension/pulmonary arterial hypertension. Proceedings of Pulmonary Hypertension UP2DATE 2008 - post Dana Point. March 14-15, 2008. Munich, Germany. Dtsch Med Wochenschr. 2008; 133(Suppl 6):S165-218.

2. Humbert M, Sitbon O, Chaouat A, Bertocchi M, Habib G, Gressin V, Yaici A, Weitzenblum E, Cordier JF, Chabot F, Dromer C, Pison C, Reynaud-Gaubert M, Haloun A, Laurent M, Hachulla E, Simonneau G. Pulmonary arterial hypertension in France: results from a national registry. American journal of respiratory and critical care medicine. 2006; 173:1023-1030. [PubMed: 16456139]

3. Rich S, Dantzker DR, Ayres SM, Bergofsky EH, Brundage BH, Detre KM, Fishman AP, Goldring RM, Groves BM, Koerner SK. Primary pulmonary hypertension. A national prospective study. Annals of Internal Medicine. 1987; 107:216-223. [PubMed: 3605900]

4. Sullivan CC, Du L, Chu D, Cho AJ, Kido M, Wolf PL, Jamieson SW, Thistlethwaite PA. Induction of pulmonary hypertension by an angiopoietin 1/TIE2/serotonin pathway. Proceedings of the National Academy of Sciences of the United States of America. 2003; 100:12331-12336. [PubMed: 14512515]

5. Thomson JR, Machado RD, Pauciulo MW, Morgan NV, Humbert M, Elliott GC, Ward K, Yacoub M, Mikhail G, Rogers P, Newman J, Wheeler L, Higenbottam T, Gibbs JS, Egan J, Crozier A, Peacock A, Allcock R, Corris P, Loyd JE, Trembath RC, Nichols WC. Sporadic primary pulmonary hypertension is associated with germline mutations of the gene encoding BMPR-II, a receptor member of the TGF-beta family. Journal of medical genetics. 2000; 37:741-745. [PubMed: 11015450]

6. Gielis JF, Lin JY, Wingler K, Van Schil PE, Schmidt HH, Moens AL. Pathogenetic role of eNOS uncoupling in cardiopulmonary disorders. Free Radic Biol Med. 2011; 50:765-776. [PubMed: 21172428]

7. Adnot S, Raffestin B, Eddahibi S, Braquet P, Chabrier PE. Loss of endothelium-dependent relaxant activity in the pulmonary circulation of rats exposed to chronic hypoxia. J Clin Invest. 1991; 87:155-162. [PubMed: 1985092]

8. Barman SA. Vasoconstrictor effect of endothelin-1 on hypertensive pulmonary arterial smooth muscle involves Rho-kinase and protein kinase C. American journal of physiology. Lung cellular and molecular physiology. 2007; 293:L472-479. [PubMed: 17468135]

9. Rich S, Kaufmann E, Levy PS. The effect of high doses of calcium-channel blockers on survival in primary pulmonary hypertension. The New England journal of medicine. 1992; 327:76-81. [PubMed: 1603139]

10. Schermuly RT, KK, Ghofrani HA, Samidurai A, Pullamsetti S, Weissmann N, Schudt C, Ermert L, Seeger W, Grimminger F. Antiremodeling effects of iloprost and the dual-selective phosphodiesterase 3/4 inhibitor tolafentrine in chronic experimental pulmonary hypertension. Circ Res. 2004; 94:1101-1108. [PubMed: 15031263]

11. Hallioglu ODE, Celiker A. Comparison of acute hemodynamic effects of aerosolized and intravenous iloprost in secondary pulmonary hypertension in children with congenital heart 
disease. Hallioglu O, Dilber E, Celiker A. Am J Cardiol. 2003; 92:1007-1009. [PubMed: 14556887]

12. Wang HGM, Zhou B, Dai A. Comparison of inhaled and intravenous milrinone in patients with pulmonary hypertension undergoing mitral valve surgery. Adv Ther. 2009; 26:462-468. [PubMed: 19381522]

13. Lai YL, Wu HD, Chen CF. Antioxidants attenuate chronic hypoxic pulmonary hypertension. J Cardiovasc Pharmacol. 1998; 32:714-720. [PubMed: 9821844]

14. Hoshikawa Y, Ono S, Suzuki S, Tanita T, Chida M, Song C, Noda M, Tabata T, Voelkel NF, Fujimura S. Generation of oxidative stress contributes to the development of pulmonary hypertension induced by hypoxia. J Appl Physiol. 2001; 90:1299-1306. [PubMed: 11247927]

15. Elmedal B, de Dam MY, Mulvany MJ, Simonsen U. The superoxide dismutase mimetic, tempol, blunts right ventricular hypertrophy in chronic hypoxic rats. Br J Pharmacol. 2004; 141:105-113. [PubMed: 14656807]

16. Wanstall JC, Kaye JA, Gambino A. The in vitro pulmonary vascular effects of FK409 (nitric oxide donor): a study in normotensive and pulmonary hypertensive rats. British journal of pharmacology. 1997; 121:280-286. [PubMed: 9154338]

17. Brennan LA, Steinhorn RH, Wedgwood S, Mata-Greenwood E, Roark EA, Russell JA, Black SM. Increased superoxide generation is associated with pulmonary hypertension in fetal lambs: a role for NADPH oxidase. Circ Res. 2003; 92:683-691. [PubMed: 12609968]

18. Jernigan NL, Walker BR, Resta TC. Endothelium-derived reactive oxygen species and endothelin-1 attenuate NO-dependent pulmonary vasodilation following chronic hypoxia. Am J Physiol Lung Cell Mol Physiol. 2004; 287:L801-808. [PubMed: 15180921]

19. Cai H, Harrison DG. Endothelial dysfunction in cardiovascular diseases: the role of oxidant stress. Circ Res. 2000; 87:840-844. [PubMed: 11073878]

20. Li H, Forstermann U. Nitric oxide in the pathogenesis of vascular disease. J Pathol. 2000; 190:244-254. [PubMed: 10685059]

21. Li D, Zhou N, Johns RA. Soluble guanylate cyclase gene expression and localization in rat lung after exposure to hypoxia. Am J Physiol. 1999; 277:L841-847. [PubMed: 10516227]

22. Jernigan NL, Walker BR, Resta TC. Pulmonary PKG-1 is upregulated following chronic hypoxia. Am J Physiol Lung Cell Mol Physiol. 2003; 285:L634-642. [PubMed: 12765880]

23. Liu JQ, Zelko IN, Erbynn EM, Sham JS, Folz RJ. Hypoxic pulmonary hypertension: role of superoxide and NADPH oxidase (gp91phox). American journal of physiology. Lung cellular and molecular physiology. 2006; 290:L2-10. [PubMed: 16085672]

24. Li S, Tabar SS, Malec V, Eul BG, Klepetko W, Weissmann N, Grimminger F, Seeger W, Rose F, Hanze J. NOX4 regulates ROS levels under normoxic and hypoxic conditions, triggers proliferation, and inhibits apoptosis in pulmonary artery adventitial fibroblasts. Antioxid Redox Signal. 2008; 10:1687-1698. [PubMed: 18593227]

25. Mittal M, Roth M, Konig P, Hofmann S, Dony E, Goyal P, Selbitz AC, Schermuly RT, Ghofrani HA, Kwapiszewska G, Kummer W, Klepetko W, Hoda MA, Fink L, Hanze J, Seeger W, Grimminger F, Schmidt HH, Weissmann N. Hypoxia-dependent regulation of nonphagocytic NADPH oxidase subunit NOX4 in the pulmonary vasculature. Circ Res. 2007; 101:258-267. [PubMed: 17585072]

26. Sturrock A, Cahill B, Norman K, Huecksteadt TP, Hill K, Sanders K, Karwande SV, Stringham JC, Bull DA, Gleich M, Kennedy TP, Hoidal JR. Transforming growth factor-beta1 induces Nox4 $\mathrm{NAD}(\mathrm{P}) \mathrm{H}$ oxidase and reactive oxygen species-dependent proliferation in human pulmonary artery smooth muscle cells. Am J Physiol Lung Cell Mol Physiol. 2006; 290:L661-L673. [PubMed: 16227320]

27. Ismail S, Sturrock A, Wu P, Cahill B, Norman K, Huecksteadt T, Sanders K, Kennedy T, Hoidal J. NOX4 mediates hypoxia-induced proliferation of human pulmonary artery smooth muscle cells: the role of autocrine production of transforming growth factor- $\{$ beta $\} 1$ and insulin-like growth factor binding protein-3. Am J Physiol Lung Cell Mol Physiol. 2009; 296:L489-499. [PubMed: 19036873]

28. Chatterjee A, Black SM, Catravas JD. Endothelial nitric oxide (NO) and its pathophysiologic regulation. Vascul Pharmacol. 2008; 49:134-140. [PubMed: 18692595] 
29. Mandegar M, Fung YC, Huang W, Remillard CV, Rubin LJ, Yuan JX. Cellular and molecular mechanisms of pulmonary vascular remodeling: role in the development of pulmonary hypertension. Microvascular research. 2004; 68:75-103. [PubMed: 15313118]

30. Rabinovitch M. Molecular pathogenesis of pulmonary arterial hypertension. J Clin Invest. 2008; 118:2372-2379. [PubMed: 18596905]

31. Wedgwood S, McMullan DM, Bekker JM, Fineman JR, Black SM. Role for endothelin-1-induced superoxide and peroxynitrite production in rebound pulmonary hypertension associated with inhaled nitric oxide therapy. Circ Res. 2001; 89:357-364. [PubMed: 11509453]

32. Grobe AC, Wells SM, Benavidez E, Oishi P, Azakie A, Fineman JR, Black SM. Increased oxidative stress in lambs with increased pulmonary blood flow and pulmonary hypertension: role of NADPH oxidase and endothelial NO synthase. Am J Physiol Lung Cell Mol Physiol. 2006; 290:L1069-1077. [PubMed: 16684951]

33. Karuppiah K, Druhan L, Chen CA, Smith T, Zweier JL, Sessa WC, Cardounel AJ. Suppression of eNOS-Derived Superoxide by Caveolin-1: A Biopterin-Dependent Mechanism. Am J Physiol Heart Circ Physiol. 2011; 301:H903-911. [PubMed: 21724868]

34. Moncada S, Higgs A. The L-arginine-nitric oxide pathway. N Engl J Med. 1993; 329:2002-2012. [PubMed: 7504210]

35. Moncada S, Higgs EA. Molecular mechanisms and therapeutic strategies related to nitric oxide. FASEB J. 1995; 9:1319-1330. [PubMed: 7557022]

36. Moncada S, Higgs EA. The discovery of nitric oxide and its role in vascular biology. Br J Pharmacol. 2006; 147(Suppl 1):S193-201. [PubMed: 16402104]

37. Kibbe MR, Li J, Nie S, Watkins SC, Lizonova A, Kovesdi I, Simmons RL, Billiar TR, Tzeng E. Inducible nitric oxide synthase (iNOS) expression upregulates p21 and inhibits vascular smooth muscle cell proliferation through p42/44 mitogen-activated protein kinase activation and independent of p53 and cyclic guanosine monophosphate. J Vasc Surg. 2000; 31:1214-1228. [PubMed: 10842159]

38. Zuckerbraun BS, Stoyanovsky DA, Sengupta R, Shapiro RA, Ozanich BA, Rao J, Barbato JE, Tzeng E. Nitric oxide-induced inhibition of smooth muscle cell proliferation involves S-nitrosation and inactivation of RhoA. Am J Physiol Cell Physiol. 2007; 292:C824-831. [PubMed: 16914531]

39. Sharma S, Sud N, Wiseman DA, Carter AL, Kumar S, Hou Y, Rau T, Wilham J, Harmon C, Oishi P, Fineman JR, Black SM. Altered carnitine homeostasis is associated with decreased mitochondrial function and altered nitric oxide signaling in lambs with pulmonary hypertension. Am J Physiol Lung Cell Mol Physiol. 2008; 294:L46-56. [PubMed: 18024721]

40. Xue C, Johns RA. Endothelial nitric oxide synthase in the lungs of patients with pulmonary hypertension. N Engl J Med. 1995; 333:1642-1644. [PubMed: 7477212]

41. Giaid A, Saleh D. Reduced expression of endothelial nitric oxide synthase in the lungs of patients with pulmonary hypertension. The New England journal of medicine. 1995; 333:214-221. [PubMed: 7540722]

42. Tuder RM, Cool CD, Geraci MW, Wang J, Abman SH, Wright L, Badesch D, Voelkel NF. Prostacyclin synthase expression is decreased in lungs from patients with severe pulmonary hypertension. Am J Respir Crit Care Med. 1999; 159:1925-1932. [PubMed: 10351941]

43. Hsu LL, Champion HC, Campbell-Lee SA, Bivalacqua TJ, Manci EA, Diwan BA, Schimel DM, Cochard AE, Wang X, Schechter AN, Noguchi CT, Gladwin MT. Hemolysis in sickle cell mice causes pulmonary hypertension due to global impairment in nitric oxide bioavailability. Blood. 2007; 109:3088-3098. [PubMed: 17158223]

44. Hu W, Jin R, Zhang J, You T, Peng Z, Ge X, Bronson RT, Halperin JA, Loscalzo J, Qin X. The critical roles of platelet activation and reduced NO bioavailability in fatal pulmonary arterial hypertension in a murine hemolysis model. Blood. 2010; 116:1613-1622. [PubMed: 20511540]

45. Khoo JP, Zhao L, Alp NJ, Bendall JK, Nicoli T, Rockett K, Wilkins MR, Channon KM. Pivotal role for endothelial tetrahydrobiopterin in pulmonary hypertension. Circulation. 2005; 111:21262133. [PubMed: 15824200]

46. Christman BW, McPherson CD, Newman JH, King GA, Bernard GR, Groves BM, Loyd JE. An imbalance between the excretion of thromboxane and prostacyclin metabolites in pulmonary hypertension. The New England journal of medicine. 1992; 327:70-75. [PubMed: 1603138] 
47. Atz AM, Adatia I, Wessel DL. Rebound pulmonary hypertension after inhalation of nitric oxide. Ann Thorac Surg. 1996; 62:1759-1764. [PubMed: 8957383]

48. Black SM, Heidersbach RS, McMullan DM, Bekker JM, Johengen MJ, Fineman JR. Inhaled nitric oxide inhibits NOS activity in lambs: potential mechanism for rebound pulmonary hypertension. Am J Physiol. 1999; 277:H1849-1856. [PubMed: 10564139]

49. Benjamin N, O’Driscoll F, Dougall H, Duncan C, Smith L, Golden M, McKenzie H. Stomach NO synthesis. Nature. 1994; 368:502. [PubMed: 8139683]

50. Zweier JL, Wang P, Samouilov A, Kuppusamy P. Enzyme-independent formation of nitric oxide in biological tissues. Nat Med. 1995; 1:804-809. [PubMed: 7585184]

51. Hunter CJ, Dejam A, Blood AB, Shields H, Kim-Shapiro DB, Machado RF, Tarekegn S, Mulla N, Hopper AO, Schechter AN, Power GG, Gladwin MT. Inhaled nebulized nitrite is a hypoxiasensitive NO-dependent selective pulmonary vasodilator. Nat Med. 2004; 10:1122-1127. [PubMed: 15361865]

52. Lundberg JO, Weitzberg E, Gladwin MT. The nitrate-nitrite-nitric oxide pathway in physiology and therapeutics. Nat Rev Drug Discov. 2008; 7:156-167. [PubMed: 18167491]

53. Snow JB, Kitzis V, Norton CE, Torres SN, Johnson KD, Kanagy NL, Walker BR, Resta TC. Differential effects of chronic hypoxia and intermittent hypocapnic and eucapnic hypoxia on pulmonary vasoreactivity. J Appl Physiol. 2008; 104:110-118. [PubMed: 17947499]

54. Resta TC, O'Donaughy TL, Earley S, Chicoine LG, Walker BR. Unaltered vasoconstrictor responsiveness after iNOS inhibition in lungs from chronically hypoxic rats. Am J Physiol. 1999; 276:L122-130. [PubMed: 9887064]

55. Demoncheaux EA, Higenbottam TW, Kiely DG, Wong JM, Wharton S, Varcoe R, Siddons T, Spivey AC, Hall K, Gize AP. Decreased whole body endogenous nitric oxide production in patients with primary pulmonary hypertension. J Vasc Res. 2005; 42:133-136. [PubMed: 15665548]

56. Weerackody RP, Welsh DJ, Wadsworth RM, Peacock AJ. Inhibition of p38 MAPK reverses hypoxia-induced pulmonary artery endothelial dysfunction. Am J Physiol Heart Circ Physiol. 2009; 296:H1312-1320. [PubMed: 19201999]

57. Beckman JS, Koppenol WH. Nitric oxide, superoxide, and peroxynitrite: the good, the bad, and ugly. Am J Physiol. 1996; 271:C1424-1437. [PubMed: 8944624]

58. Kunuthur SP, Milliken PH, Gibson CL, Suckling CJ, Wadsworth RM. Tetrahydrobiopterin analogues with NO-dependent pulmonary vasodilator properties. Eur J Pharmacol. 2011; 650:6.

59. Cunnington C, Channon KM. Tetrahydrobiopterin: pleiotropic roles in cardiovascular pathophysiology. Heart. 2010; 96:1872-1877. [PubMed: 20837663]

60. Crabtree MJ, Tatham AL, Al-Wakeel Y, Warrick N, Hale AB, Cai S, Channon KM, Alp NJ. Quantitative regulation of intracellular endothelial nitric-oxide synthase (eNOS) coupling by both tetrahydrobiopterin-eNOS stoichiometry and biopterin redox status: insights from cells with tetregulated GTP cyclohydrolase I expression. J Biol Chem. 2009; 284:1136-1144. [PubMed: 19011239]

61. Francis BN, Wilkins MR, Zhao L. Tetrahydrobiopterin and the regulation of hypoxic pulmonary vasoconstriction. Eur Respir J. 2010; 36:323-330. [PubMed: 20223914]

62. Bernatchez PN, Bauer PM, Yu J, Prendergast JS, He P, Sessa WC. Dissecting the molecular control of endothelial NO synthase by caveolin-1 using cell-permeable peptides. Proc Natl Acad Sci U S A. 2005; 102:761-766. [PubMed: 15637154]

63. Garcia-Cardena G, Martasek P, Masters BS, Skidd PM, Couet J, Li S, Lisanti MP, Sessa WC. Dissecting the interaction between nitric oxide synthase (NOS) and caveolin. Functional significance of the nos caveolin binding domain in vivo. J Biol Chem. 1997; 272:25437-25440. [PubMed: 9325253]

64. Maniatis NA, Shinin V, Schraufnagel DE, Okada S, Vogel SM, Malik AB, Minshall RD. Increased pulmonary vascular resistance and defective pulmonary artery filling in caveolin-1-/- mice. Am J Physiol Lung Cell Mol Physiol. 2008; 294:L865-873. [PubMed: 18192592]

65. Wunderlich C, Schober K, Schmeisser A, Heerwagen C, Tausche AK, Steinbronn N, Brandt A, Kasper M, Schwencke C, Braun-Dullaeus RC, Strasser RH. The adverse cardiopulmonary 
phenotype of caveolin-1 deficient mice is mediated by a dysfunctional endothelium. J Mol Cell Cardiol. 2008; 44:938-947. [PubMed: 18417152]

66. Wunderlich C, Schmeisser A, Heerwagen C, Ebner B, Schober K, Braun-Dullaeus RC, Schwencke C, Kasper M, Morawietz H, Strasser RH. Chronic NOS inhibition prevents adverse lung remodeling and pulmonary arterial hypertension in caveolin-1 knockout mice. Pulm Pharmacol Ther. 2008; 21:507-515. [PubMed: 18226570]

67. Murata T, Lin MI, Huang Y, Yu J, Bauer PM, Giordano FJ, Sessa WC. Reexpression of caveolin-1 in endothelium rescues the vascular, cardiac, and pulmonary defects in global caveolin-1 knockout mice. J Exp Med. 2007; 204:2373-2382. [PubMed: 17893196]

68. Ozaki M, Kawashima S, Yamashita T, Ohashi Y, Rikitake Y, Inoue N, Hirata KI, Hayashi Y, Itoh H, Yokoyama M. Reduced hypoxic pulmonary vascular remodeling by nitric oxide from the endothelium. Hypertension. 2001; 37:322-327. [PubMed: 11230292]

69. Ozaki M, Kawashima S, Yamashita T, Hirase T, Namiki M, Inoue N, Hirata K, Yasui H, Sakurai H, Yoshida Y, Masada M, Yokoyama M. Overexpression of endothelial nitric oxide synthase accelerates atherosclerotic lesion formation in apoE-deficient mice. J Clin Invest. 2002; 110:331340. [PubMed: 12163452]

70. Zhao YY, Zhao YD, Mirza MK, Huang JH, Potula HH, Vogel SM, Brovkovych V, Yuan JX, Wharton J, Malik AB. Persistent eNOS activation secondary to caveolin-1 deficiency induces pulmonary hypertension in mice and humans through PKG nitration. J Clin Invest. 2009; 119:2009-2018. [PubMed: 19487814]

71. Knorr MHM, Kröller-Schuhmacher S, Steven S, Oelze M, Heeren T, Scholz A, Gori T, Wenzel P, Schulz E, Daiber A, Münzel T. Nitroglycerin-induced endothelial dysfunction and tolerance involve adverse phosphorylation and S-Glutathionylation of endothelial nitric oxide synthase: beneficial effects of therapy with the AT1 receptor blocker telmisartan. Arterioscler Thromb Vasc Biol. 2011; 31:2223-2231. [PubMed: 21757654]

72. Chen CA, WT, Varadharaj S, Reyes LA, Hemann C, Talukder MA, Chen YR, Druhan LJ, Zweier JL. S-glutathionylation uncouples eNOS and regulates its cellular and vascular function. Nature. 2010; 468:1115-1118. [PubMed: 21179168]

73. Sheehy AM, Burson MA, Black SM. Nitric oxide exposure inhibits endothelial NOS activity but not gene expression: a role for superoxide. Am J Physiol. 1998; 274:L833-841. [PubMed: 9612300]

74. Deruelle P, Grover TR, Abman SH. Pulmonary vascular effects of nitric oxide-cGMP augmentation in a model of chronic pulmonary hypertension in fetal and neonatal sheep. Am $\mathbf{J}$ Physiol Lung Cell Mol Physiol. 2005; 289:L798-806. [PubMed: 15964898]

75. Tsai EJ, Kass DA. Cyclic GMP signaling in cardiovascular pathophysiology and therapeutics. Pharmacol Ther. 2009; 122:216-238. [PubMed: 19306895]

76. Schermuly RT, Stasch JP, Pullamsetti SS, Middendorff R, Muller D, Schluter KD, Dingendorf A, Hackemack S, Kolosionek E, Kaulen C, Dumitrascu R, Weissmann N, Mittendorf J, Klepetko W, Seeger W, Ghofrani HA, Grimminger F. Expression and function of soluble guanylate cyclase in pulmonary arterial hypertension. Eur Respir J. 2008; 32:881-891. [PubMed: 18550612]

77. Kirsch M, Kemp-Harper B, Weissmann N, Grimminger F, Schmidt HH. Sildenafil in hypoxic pulmonary hypertension potentiates a compensatory up-regulation of NO-cGMP signaling. FASEB J. 2008; 22:30-40. [PubMed: 17679609]

78. Sebkhi A, Strange JW, Phillips SC, Wharton J, Wilkins MR. Phosphodiesterase type 5 as a target for the treatment of hypoxia-induced pulmonary hypertension. Circulation. 2003; 107:3230-3235. [PubMed: 12796132]

79. Zhao L, Mason NA, Morrell NW, Kojonazarov B, Sadykov A, Maripov A, Mirrakhimov MM, Aldashev A, Wilkins MR. Sildenafil inhibits hypoxia-induced pulmonary hypertension. Circulation. 2001; 104:424-428. [PubMed: 11468204]

80. Gladwin MT, Sachdev V, Jison ML, Shizukuda Y, Plehn JF, Minter K, Brown B, Coles WA, Nichols JS, Ernst I, Hunter LA, Blackwelder WC, Schechter AN, Rodgers GP, Castro O, Ognibene FP. Pulmonary hypertension as a risk factor for death in patients with sickle cell disease. N Engl J Med. 2004; 350:886-895. [PubMed: 14985486] 
81. Gladwin MT, Vichinsky E. Pulmonary complications of sickle cell disease. N Engl J Med. 2008; 359:2254-2265. [PubMed: 19020327]

82. Reiter CD, Wang X, Tanus-Santos JE, Hogg N, Cannon RO 3rd, Schechter AN, Gladwin MT. Cell-free hemoglobin limits nitric oxide bioavailability in sickle-cell disease. Nat Med. 2002; 8:1383-1389. [PubMed: 12426562]

83. Rother RP, Bell L, Hillmen P, Gladwin MT. The clinical sequelae of intravascular hemolysis and extracellular plasma hemoglobin: a novel mechanism of human disease. JAMA. 2005; 293:16531662. [PubMed: 15811985]

84. Morris CR, Kato GJ, Poljakovic M, Wang X, Blackwelder WC, Sachdev V, Hazen SL, Vichinsky EP, Morris SM Jr, Gladwin MT. Dysregulated arginine metabolism, hemolysis-associated pulmonary hypertension, and mortality in sickle cell disease. JAMA. 2005; 294:81-90. [PubMed: 15998894]

85. Ivy DD, Parker TA, Ziegler JW, Galan HL, Kinsella JP, Tuder RM, Abman SH. Prolonged endothelin A receptor blockade attenuates chronic pulmonary hypertension in the ovine fetus. J Clin Invest. 1997; 99:1179-1186. [PubMed: 9077525]

86. Coggins MP, Bloch KD. Nitric oxide in the pulmonary vasculature. Arteriosclerosis, Thrombosis, and Vascular Biology. 2007; 27:1877-1885.

87. Atz AM, Wessel DL. Inhaled nitric oxide in the neonate with cardiac disease. Semin Perinatol. 1997; 21:441-455. [PubMed: 9352616]

88. Markewitz BA, Michael JR. Inhaled nitric oxide in adults with the acute respiratory distress syndrome. Respir Med. 2000; 94:1023-1028. [PubMed: 11127486]

89. Roberts JD Jr, Fineman JR, Morin FC 3rd, Shaul PW, Rimar S, Schreiber MD, Polin RA, Zwass MS, Zayek MM, Gross I, Heymann MA, Zapol WM. Inhaled nitric oxide and persistent pulmonary hypertension of the newborn. The Inhaled Nitric Oxide Study Group. N Engl J Med. 1997; 336:605-610. [PubMed: 9032045]

90. Rossaint R, Falke KJ, Lopez F, Slama K, Pison U, Zapol WM. Inhaled nitric oxide for the adult respiratory distress syndrome. N Engl J Med. 1993; 328:399-405. [PubMed: 8357359]

91. Cueto E, Lopez-Herce J, Sanchez A, Carrillo A. Life-threatening effects of discontinuing inhaled nitric oxide in children. Acta Paediatr. 1997; 86:1337-1339. [PubMed: 9475312]

92. Lavoie A, Hall JB, Olson DM, Wylam ME. Life-threatening effects of discontinuing inhaled nitric oxide in severe respiratory failure. Am J Respir Crit Care Med. 1996; 153:1985-1987. [PubMed: 8665066]

93. Miller OI, Tang SF, Keech A, Celermajer DS. Rebound pulmonary hypertension on withdrawal from inhaled nitric oxide. Lancet. 1995; 346:51-52. [PubMed: 7603160]

94. Namachivayam P, Theilen U, Butt WW, Cooper SM, Penny DJ, Shekerdemian LS. Sildenafil prevents rebound pulmonary hypertension after withdrawal of nitric oxide in children. Am J Respir Crit Care Med. 2006; 174:1042-1047. [PubMed: 16917115]

95. Elkayam U. Tolerance to organic nitrates: evidence, mechanisms, clinical relevance, and strategies for prevention. Ann Intern Med. 1991; 114:667-677. [PubMed: 2003715]

96. Munzel T, Sayegh H, Freeman BA, Tarpey MM, Harrison DG. Evidence for enhanced vascular superoxide anion production in nitrate tolerance. A novel mechanism underlying tolerance and cross-tolerance. J Clin Invest. 1995; 95:187-194. [PubMed: 7814613]

97. Munzel T, Kurz S, Rajagopalan S, Thoenes M, Berrington WR, Thompson JA, Freeman BA, Harrison DG. Hydralazine prevents nitroglycerin tolerance by inhibiting activation of a membrane-bound NADH oxidase. A new action for an old drug. J Clin Invest. 1996; 98:14651470. [PubMed: 8823313]

98. Kurz S, Hink U, Nickenig G, Borthayre AB, Harrison DG, Munzel T. Evidence for a causal role of the renin-angiotensin system in nitrate tolerance. Circulation. 1999; 99:3181-3187. [PubMed: 10377083]

99. Munzel T, Giaid A, Kurz S, Stewart DJ, Harrison DG. Evidence for a role of endothelin 1 and protein kinase C in nitroglycerin tolerance. Proc Natl Acad Sci U S A. 1995; 92:5244-5248. [PubMed: 7539147]

100. Sydow K, Daiber A, Oelze M, Chen Z, August M, Wendt M, Ullrich V, Mulsch A, Schulz E, Keaney JF Jr, Stamler JS, Munzel T. Central role of mitochondrial aldehyde dehydrogenase and 
reactive oxygen species in nitroglycerin tolerance and cross-tolerance. J Clin Invest. 2004; 113:482-489. [PubMed: 14755345]

101. Modin A, Bjorne H, Herulf M, Alving K, Weitzberg E, Lundberg JO. Nitrite-derived nitric oxide: a possible mediator of 'acidic-metabolic' vasodilation. Acta Physiol Scand. 2001; 171:9-16. [PubMed: 11350258]

102. Cosby K, Partovi KS, Crawford JH, Patel RP, Reiter CD, Martyr S, Yang BK, Waclawiw MA, Zalos G, Xu X, Huang KT, Shields H, Kim-Shapiro DB, Schechter AN, Cannon RO 3rd, Gladwin MT. Nitrite reduction to nitric oxide by deoxyhemoglobin vasodilates the human circulation. Nat Med. 2003; 9:1498-1505. [PubMed: 14595407]

103. Dejam A, Hunter CJ, Schechter AN, Gladwin MT. Emerging role of nitrite in human biology. Blood Cells Mol Dis. 2004; 32:423-429. [PubMed: 15121102]

104. Gladwin MT, Shelhamer JH, Schechter AN, Pease-Fye ME, Waclawiw MA, Panza JA, Ognibene FP, Cannon RO 3rd. Role of circulating nitrite and S-nitrosohemoglobin in the regulation of regional blood flow in humans. Proc Natl Acad Sci U S A. 2000; 97:11482-11487. [PubMed: 11027349]

105. Tota B, Quintieri AM, Angelone T. The emerging role of nitrite as an endogenous modulator and therapeutic agent of cardiovascular function. Curr Med Chem. 2010; 17:1915-1925. [PubMed: 20377513]

106. Rassaf T, Flogel U, Drexhage C, Hendgen-Cotta U, Kelm M, Schrader J. Nitrite reductase function of deoxymyoglobin: oxygen sensor and regulator of cardiac energetics and function. Circ Res. 2007; 100:1749-1754. [PubMed: 17495223]

107. Huang KT, Keszler A, Patel N, Patel RP, Gladwin MT, Kim-Shapiro DB, Hogg N. The reaction between nitrite and deoxyhemoglobin. Reassessment of reaction kinetics and stoichiometry. $\mathrm{J}$ Biol Chem. 2005; 280:31126-31131. [PubMed: 15837788]

108. Flogel U, Godecke A, Klotz LO, Schrader J. Role of myoglobin in the antioxidant defense of the heart. FASEB J. 2004; 18:1156-1158. [PubMed: 15132981]

109. Tiso M, Tejero J, Basu S, Azarov I, Wang X, Simplaceanu V, Frizzell S, Jayaraman T, Geary L, Shapiro C, Ho C, Shiva S, Kim-Shapiro DB, Gladwin MT. Human neuroglobin functions as a redox-regulated nitrite reductase. J Biol Chem. 2011; 286:18277-18289. [PubMed: 21296891]

110. Shiva S, Gladwin MT. Shining a light on tissue NO stores: near infrared release of NO from nitrite and nitrosylated hemes. J Mol Cell Cardiol. 2009; 46:1-3. [PubMed: 18992252]

111. Hendgen-Cotta UB, Merx MW, Shiva S, Schmitz J, Becher S, Klare JP, Steinhoff HJ, Goedecke A, Schrader J, Gladwin MT, Kelm M, Rassaf T. Nitrite reductase activity of myoglobin regulates respiration and cellular viability in myocardial ischemia-reperfusion injury. Proc Natl Acad Sci U S A. 2008; 105:10256-10261. [PubMed: 18632562]

112. Shiva S, Huang Z, Grubina R, Sun J, Ringwood LA, MacArthur PH, Xu X, Murphy E, DarleyUsmar VM, Gladwin MT. Deoxymyoglobin is a nitrite reductase that generates nitric oxide and regulates mitochondrial respiration. Circ Res. 2007; 100:654-661. [PubMed: 17293481]

113. Zuckerbraun BS, Shiva S, Ifedigbo E, Mathier MA, Mollen KP, Rao J, Bauer PM, Choi JJ, Curtis E, Choi AM, Gladwin MT. Nitrite potently inhibits hypoxic and inflammatory pulmonary arterial hypertension and smooth muscle proliferation via xanthine oxidoreductase-dependent nitric oxide generation. Circulation. 2010; 121:98-109. [PubMed: 20026772]

114. Friebe A, Koesling D. Regulation of nitric oxide-sensitive guanylyl cyclase. Circ Res. 2003; 93:96-105. [PubMed: 12881475]

115. Galie N, Ghofrani HA, Torbicki A, Barst RJ, Rubin LJ, Badesch D, Fleming T, Parpia T, Burgess G, Branzi A, Grimminger F, Kurzyna M, Simonneau G. Sildenafil Use in Pulmonary Arterial Hypertension Study, G. Sildenafil citrate therapy for pulmonary arterial hypertension. N Engl J Med. 2005; 353:2148-2157. [PubMed: 16291984]

116. Pepke-Zaba J, Gilbert C, Collings L, Brown MC. Sildenafil improves health-related quality of life in patients with pulmonary arterial hypertension. Chest. 2008; 133:183-189. [PubMed: 18187744]

117. Palmieri EA, Affuso F, Fazio S, Lembo D. Tadalafil in primary pulmonary arterial hypertension. Ann Intern Med. 2004; 141:743-744. [PubMed: 15520445] 
118. Galie N, Brundage BH, Ghofrani HA, Oudiz RJ, Simonneau G, Safdar Z, Shapiro S, White RJ, Chan M, Beardsworth A, Frumkin L, Barst RJ. Pulmonary Arterial H Response to Tadalafil Study, G. Tadalafil therapy for pulmonary arterial hypertension. Circulation. 2009; 119:28942903. [PubMed: 19470885]

119. Evgenov OV, Pacher P, Schmidt PM, Hasko G, Schmidt HH, Stasch JP. NO-independent stimulators and activators of soluble guanylate cyclase: discovery and therapeutic potential. Nat Rev Drug Discov. 2006; 5:755-768. [PubMed: 16955067]

120. Stasch JP, Becker EM, Alonso-Alija C, Apeler H, Dembowsky K, Feurer A, Gerzer R, Minuth T, Perzborn E, Pleiss U, Schroder H, Schroeder W, Stahl E, Steinke W, Straub A, Schramm M. NOindependent regulatory site on soluble guanylate cyclase. Nature. 2001; 410:212-215. [PubMed: 11242081]

121. Mittendorf J, Weigand S, Alonso-Alija C, Bischoff E, Feurer A, Gerisch M, Kern A, Knorr A, Lang D, Muenter K, Radtke M, Schirok H, Schlemmer KH, Stahl E, Straub A, Wunder F, Stasch JP. Discovery of riociguat (BAY 63-2521): a potent, oral stimulator of soluble guanylate cyclase for the treatment of pulmonary hypertension. ChemMedChem. 2009; 4:853-865. [PubMed: 19263460]

122. Ghofrani HA, Hoeper MM, Halank M, Meyer FJ, Staehler G, Behr J, Ewert R, Weimann G, Grimminger F. Riociguat for chronic thromboembolic pulmonary hypertension and pulmonary arterial hypertension: a phase II study. Eur Respir J. 2010; 36:792-799. [PubMed: 20530034]

123. Haynes WG, Webb DJ. Endothelin as a regulator of cardiovascular function in health and disease. Journal of hypertension. 1998; 16:1081-1098. [PubMed: 9794709]

124. Staniloae C, Dupuis J, White M, Gosselin G, Dyrda I, Bois M, Crepeau J, Bonan R, Caron A, Lavoie J. Reduced pulmonary clearance of endothelin in congestive heart failure: a marker of secondary pulmonary hypertension. J Card Fail. 2004; 10:427-432. [PubMed: 15470654]

125. Duffy JY, Schwartz SM, Lyons JM, Bell JH, Wagner CJ, Zingarelli B, Pearl JM. Calpain inhibition decreases endothelin-1 levels and pulmonary hypertension after cardiopulmonary bypass with deep hypothermic circulatory arrest. Crit Care Med. 2005; 33:623-628. [PubMed: 15753756]

126. Ross GA, Oishi P, Azakie A, Fratz S, Fitzgerald RK, Johengen MJ, Harmon C, Hendricks-Munoz $\mathrm{K}, \mathrm{Xu}$ J, Black SM, Fineman JR. Endothelial alterations during inhaled NO in lambs with pulmonary hypertension: implications for rebound hypertension. Am J Physiol Lung Cell Mol Physiol. 2005; 288:L27-35. [PubMed: 15347565]

127. Sakurai T, Yanagisawa M, Takuwa Y, Miyazaki H, Kimura S, Goto K, Masaki T. Cloning of a cDNA encoding a non-isopeptide-selective subtype of the endothelin receptor. Nature. 1990; 348:732-735. [PubMed: 2175397]

128. Arai H, Hori S, Aramori I, Ohkubo H, Nakanishi S. Cloning and expression of a cDNA encoding an endothelin receptor. Nature. 1990; 348:730-732. [PubMed: 2175396]

129. Zamora MA, Dempsey EC, Walchak SJ, Stelzner TJ. BQ123, an ETA receptor antagonist, inhibits endothelin-1-mediated proliferation of human pulmonary artery smooth muscle cells. Am J Respir Cell Mol Biol. 1993; 9:429-433. [PubMed: 8398181]

130. Sato K, Oka M, Hasunuma K, Ohnishi M, Kira S. Effects of separate and combined ETA and ETB blockade on ET-1-induced constriction in perfused rat lungs. Am J Physiol. 1995; 269:L668-672. [PubMed: 7491987]

131. Shichiri M, Kato H, Marumo F, Hirata Y. Endothelin-1 as an autocrine/paracrine apoptosis survival factor for endothelial cells. Hypertension. 1997; 30:1198-1203. [PubMed: 9369276]

132. Soma S, Takahashi H, Muramatsu M, Oka M, Fukuchi Y. Localization and distribution of endothelin receptor subtypes in pulmonary vasculature of normal and hypoxia-exposed rats. Am J Respir Cell Mol Biol. 1999; 20:620-630. [PubMed: 10100993]

133. Li H, Elton TS, Chen YF, Oparil S. Increased endothelin receptor gene expression in hypoxic rat lung. Am J Physiol. 1994; 266:L553-560. [PubMed: 8203548]

134. Wedgwood S, Black SM. Endothelin-1 decreases endothelial NOS expression and activity through ETA receptor-mediated generation of hydrogen peroxide. Am J Physiol Lung Cell Mol Physiol. 2005; 288:L480-487. [PubMed: 15531748] 
135. Dai ZK, Tan MS, Chai CY, Chou SH, Lin PC, Yeh JL, Jeng AY, Chang CI, Chen IJ, Wu JR. Effects of sildenafil on pulmonary hypertension and levels of ET-1, eNOS, and cGMP in aortabanded rats. Exp Biol Med (Maywood). 2006; 231:942-947. [PubMed: 16741028]

136. Redmond EM, Cahill PA, Hodges R, Zhang S, Sitzmann JV. Regulation of endothelin receptors by nitric oxide in cultured rat vascular smooth muscle cells. J Cell Physiol. 1996; 166:469-479. [PubMed: 8600150]

137. Boulanger C, Luscher TF. Release of endothelin from the porcine aorta. Inhibition by endothelium-derived nitric oxide. J Clin Invest. 1990; 85:587-590. [PubMed: 2153712]

138. Wedgwood S, Dettman RW, Black SM. ET-1 stimulates pulmonary arterial smooth muscle cell proliferation via induction of reactive oxygen species. Am J Physiol Lung Cell Mol Physiol. 2001; 281:L1058-1067. [PubMed: 11597896]

139. Cheng TH, Shih NL, Chen SY, Loh SH, Cheng PY, Tsai CS, Liu SH, Wang DL, Chen JJ. Reactive oxygen species mediate cyclic strain-induced endothelin-1 gene expression via Ras/Raf/ extracellular signal-regulated kinase pathway in endothelial cells. J Mol Cell Cardiol. 2001; 33:1805-1814. [PubMed: 11603923]

140. Kyaw M, Yoshizumi M, Tsuchiya K, Kirima K, Suzaki Y, Abe S, Hasegawa T, Tamaki T. Antioxidants inhibit endothelin-1 (1-31)-induced proliferation of vascular smooth muscle cells via the inhibition of mitogen-activated protein (MAP) kinase and activator protein-1 (AP-1). Biochem Pharmacol. 2002; 64:1521-1531. [PubMed: 12417265]

141. Fei J, Viedt C, Soto U, Elsing C, Jahn L, Kreuzer J. Endothelin-1 and smooth muscle cells: induction of jun amino-terminal kinase through an oxygen radical-sensitive mechanism. Arterioscler Thromb Vasc Biol. 2000; 20:1244-1249. [PubMed: 10807739]

142. Rubin LJ, Badesch DB, Barst RJ, Galie N, Black CM, Keogh A, Pulido T, Frost A, Roux S, Leconte I, Landzberg M, Simonneau G. Bosentan therapy for pulmonary arterial hypertension. N Engl J Med. 2002; 346:896-903. [PubMed: 11907289]

143. Barst RJ, Ivy D, Dingemanse J, Widlitz A, Schmitt K, Doran A, Bingaman D, Nguyen N, Gaitonde M, van Giersbergen PL. Pharmacokinetics, safety, and efficacy of bosentan in pediatric patients with pulmonary arterial hypertension. Clin Pharmacol Ther. 2003; 73:372-382. [PubMed: 12709727]

144. Hardy H, Backman ES, Farber HW. Successful bosentan and nonnucleoside reverse transcriptase inhibitor-based therapy in a patient with acquired immunodeficiency syndrome and pulmonary arterial hypertension. Pharmacotherapy. 2010; 30:139e-144e.

145. Hoeper MM, Seyfarth HJ, Hoeffken G, Wirtz H, Spiekerkoetter E, Pletz MW, Welte T, Halank M. Experience with inhaled iloprost and bosentan in portopulmonary hypertension. Eur Respir J. 2007; 30:1096-1102. [PubMed: 17652314]

146. Channick RN, Simonneau G, Sitbon O, Robbins IM, Frost A, Tapson VF, Badesch DB, Roux S, Rainisio M, Bodin F, Rubin LJ. Effects of the dual endothelin-receptor antagonist bosentan in patients with pulmonary hypertension: a randomised placebo-controlled study. Lancet. 2001; 358:1119-1123. [PubMed: 11597664]

147. Galie N, Olschewski H, Oudiz RJ, Torres F, Frost A, Ghofrani HA, Badesch DB, McGoon MD, McLaughlin VV, Roecker EB, Gerber MJ, Dufton C, Wiens BL, Rubin LJ. Ambrisentan in Pulmonary Arterial Hypertension RD-BP-CMESG. Ambrisentan for the treatment of pulmonary arterial hypertension: results of the ambrisentan in pulmonary arterial hypertension, randomized, double-blind, placebo-controlled, multicenter, efficacy (ARIES) study 1 and 2. Circulation. 2008; 117:3010-3019. [PubMed: 18506008]

148. Hartman JC, Brouwer K, Mandagere A, Melvin L, Gorczynski R. Evaluation of the endothelin receptor antagonists ambrisentan, darusentan, bosentan, and sitaxsentan as substrates and inhibitors of hepatobiliary transporters in sandwich-cultured human hepatocytes. Can J Physiol Pharmacol. 2010; 88:682-691. [PubMed: 20628435]

149. Wedgwood S, Bekker JM, Black SM. Shear stress regulation of endothelial NOS in fetal pulmonary arterial endothelial cells involves PKC. American journal of physiology. Lung cellular and molecular physiology. 2001; 281:L490-498. [PubMed: 11435225]

150. DeMarco VG, Habibi J, Whaley-Connell AT, Schneider RI, Heller RL, Bosanquet JP, Hayden MR, Delcour K, Cooper SA, Andresen BT, Sowers JR, Dellsperger KC. Oxidative stress 
contributes to pulmonary hypertension in the transgenic (mRen2)27 rat. Am J Physiol Heart Circ Physiol. 2008; 294:H2659-2668. [PubMed: 18424632]

151. Jankov RP, Kantores C, Pan J, Belik J. Contribution of xanthine oxidase-derived superoxide to chronic hypoxic pulmonary hypertension in neonatal rats. Am J Physiol Lung Cell Mol Physiol. 2008; 294:L233-245. [PubMed: 18083771]

152. Joppa P, Petrasova D, Stancak B, Dorkova Z, Tkacova R. Oxidative stress in patients with COPD and pulmonary hypertension. Wien Klin Wochenschr. 2007; 119:428-434. [PubMed: 17671825]

153. Rathore R, Zheng YM, Niu CF, Liu QH, Korde A, Ho YS, Wang YX. Hypoxia activates NADPH oxidase to increase [ROS]i and [Ca2+]i through the mitochondrial ROS-PKCepsilon signaling axis in pulmonary artery smooth muscle cells. Free Radic Biol Med. 2008; 45:1223-1231. [PubMed: 18638544]

154. Baas AS, Berk BC. Differential activation of mitogen-activated protein kinases by $\mathrm{H} 2 \mathrm{O} 2$ and $\mathrm{O} 2$ in vascular smooth muscle cells. Circ Res. 1995; 77:29-36. [PubMed: 7540516]

155. Rao GN, Berk BC. Active oxygen species stimulate vascular smooth muscle cell growth and proto-oncogene expression. Circ Res. 1992; 70:593-599. [PubMed: 1371430]

156. Rao GN, Lassegue B, Griendling KK, Alexander RW. Hydrogen peroxide stimulates transcription of c-jun in vascular smooth muscle cells: role of arachidonic acid. Oncogene. 1993; 8:2759-2764. [PubMed: 8378085]

157. Sundaresan M, Yu ZX, Ferrans VJ, Irani K, Finkel T. Requirement for generation of $\mathrm{H} 2 \mathrm{O} 2$ for platelet-derived growth factor signal transduction. Science. 1995; 270:296-299. [PubMed: 7569979]

158. Madjdpour C, Jewell UR, Kneller S, Ziegler U, Schwendener R, Booy C, Klausli L, Pasch T, Schimmer RC, Beck-Schimmer B. Decreased alveolar oxygen induces lung inflammation. Am J Physiol Lung Cell Mol Physiol. 2003; 284:L360-367. [PubMed: 12388372]

159. Stenmark KR, Davie NJ, Reeves JT, Frid MG. Hypoxia, leukocytes, and the pulmonary circulation. J Appl Physiol. 2005; 98:715-721. [PubMed: 15649883]

160. Linseman DA, Benjamin CW, Jones DA. Convergence of angiotensin II and platelet-derived growth factor receptor signaling cascades in vascular smooth muscle cells. The Journal of biological chemistry. 1995; 270:12563-12568. [PubMed: 7759503]

161. Sausbier M, Schubert R, Voigt V, Hirneiss C, Pfeifer A, Korth M, Kleppisch T, Ruth P, Hofmann F. Mechanisms of NO/cGMP-dependent vasorelaxation. Circ Res. 2000; 87:825-830. [PubMed: 11055988]

162. Negash S, Gao Y, Zhou W, Liu J, Chinta S, Raj JU. Regulation of cGMP-dependent protein kinase-mediated vasodilation by hypoxia-induced reactive species in ovine fetal pulmonary veins. Am J Physiol Lung Cell Mol Physiol. 2007; 293:L1012-1020. [PubMed: 17616649]

163. Aggarwal S, Gross CM, Kumar S, Datar S, Oishi P, Kalka G, Schreiber C, Fratz S, Fineman JR, Black SM. Attenuated vasodilatation in lambs with endogenous and exogenous activation of cGMP signaling: Role of protein kinase G nitration. J Cell Physiol. 2011; 226:3104-3113. [PubMed: 21351102]

164. Agbani EO, Coats P, Mills A, Wadsworth RM. Peroxynitrite stimulates pulmonary artery endothelial and smooth muscle cell proliferation: involvement of ERK and PKC. Pulm Pharmacol Ther. 2011; 24:100-109. [PubMed: 20851205]

165. Zou MH, Cohen R, Ullrich V. Peroxynitrite and vascular endothelial dysfunction in diabetes mellitus. Endothelium. 2004; 11:89-97. [PubMed: 15370068]

166. Nie H, Wu JL, Zhang M, Xu J, Zou MH. Endothelial nitric oxide synthase-dependent tyrosine nitration of prostacyclin synthase in diabetes in vivo. Diabetes. 2006; 55:3133-3141. [PubMed: 17065353]

167. Mohazzab KM, Wolin MS. Sites of superoxide anion production detected by lucigenin in calf pulmonary artery smooth muscle. Am J Physiol. 1994; 267:L815-822. [PubMed: 7810685]

168. Jones SA, O’Donnell VB, Wood JD, Broughton JP, Hughes EJ, Jones OT. Expression of phagocyte NADPH oxidase components in human endothelial cells. Am J Physiol. 1996; 271:H1626-1634. [PubMed: 8897960] 
169. Griendling KK, Minieri CA, Ollerenshaw JD, Alexander RW. Angiotensin II stimulates NADH and NADPH oxidase activity in cultured vascular smooth muscle cells. Circ Res. 1994; 74:11411148. [PubMed: 8187280]

170. Pagano PJ, Ito Y, Tornheim K, Gallop PM, Tauber AI, Cohen RA. An NADPH oxidase superoxide-generating system in the rabbit aorta. Am J Physiol. 1995; 268:H2274-2280. [PubMed: 7611477]

171. Pagano PJ, Clark JK, Cifuentes-Pagano ME, Clark SM, Callis GM, Quinn MT. Localization of a constitutively active, phagocyte-like NADPH oxidase in rabbit aortic adventitia: enhancement by angiotensin II. Proc Natl Acad Sci U S A. 1997; 94:14483-14488. [PubMed: 9405639]

172. Dennis KE, Aschner JL, Milatovic D, Schmidt JW, Aschner M, Kaplowitz MR, Zhang Y, Fike CD. NADPH oxidases and reactive oxygen species at different stages of chronic hypoxiainduced pulmonary hypertension in newborn piglets. Am J Physiol Lung Cell Mol Physiol. 2009; 297:L596-607. [PubMed: 19592458]

173. Fresquet F, Pourageaud F, Leblais V, Brandes RP, Savineau JP, Marthan R, Muller B. Role of reactive oxygen species and gp91phox in endothelial dysfunction of pulmonary arteries induced by chronic hypoxia. Br J Pharmacol. 2006; 148:714-723. [PubMed: 16715116]

174. Fike CD, Slaughter JC, Kaplowitz MR, Zhang Y, Aschner JL. Reactive oxygen species from NADPH oxidase contribute to altered pulmonary vascular responses in piglets with chronic hypoxia-induced pulmonary hypertension. Am J Physiol Lung Cell Mol Physiol. 2008; 295:L881-888. [PubMed: 18757525]

175. Lee SL, Wang WW, Finlay GA, Fanburg BL. Serotonin stimulates mitogen-activated protein kinase activity through the formation of superoxide anion. Am J Physiol. 1999; 277:L282-291. [PubMed: 10444522]

176. Lee SL, Simon AR, Wang WW, Fanburg BL. H(2)O(2) signals 5-HT-induced ERK MAP kinase activation and mitogenesis of smooth muscle cells. Am J Physiol Lung Cell Mol Physiol. 2001; 281:L646-652. [PubMed: 11504692]

177. DeMarco VG, Habibi J, Whaley-Connell AT, Schneider RI, Sowers JR, Andresen BT, Gutweiler AA, Ma L, Johnson MS, Ferrario CM, Dellsperger KC. Rosuvastatin ameliorates the development of pulmonary arterial hypertension in the transgenic (mRen2)27 rat. Am J Physiol Heart Circ Physiol. 2009; 297:H1128-1139. [PubMed: 19633211]

178. Ferreira AJ, Shenoy V, Yamazato Y, Sriramula S, Francis J, Yuan L, Castellano RK, Ostrov DA, Oh SP, Katovich MJ, Raizada MK. Evidence for angiotensin-converting enzyme 2 as a therapeutic target for the prevention of pulmonary hypertension. Am J Respir Crit Care Med. 2009; 179:1048-1054. [PubMed: 19246717]

179. Yamazato Y, Ferreira AJ, Hong KH, Sriramula S, Francis J, Yamazato M, Yuan L, Bradford CN, Shenoy V, Oh SP, Katovich MJ, Raizada MK. Prevention of pulmonary hypertension by Angiotensin-converting enzyme 2 gene transfer. Hypertension. 2009; 54:365-371. [PubMed: 19564552]

180. Kanno S, Wu YJ, Lee PC, Billiar TR, Ho C. Angiotensin-converting enzyme inhibitor preserves p21 and endothelial nitric oxide synthase expression in monocrotaline-induced pulmonary arterial hypertension in rats. Circulation. 2001; 104:945-950. [PubMed: 11514384]

181. Nong Z, Stassen JM, Moons L, Collen D, Janssens S. Inhibition of tissue angiotensin-converting enzyme with quinapril reduces hypoxic pulmonary hypertension and pulmonary vascular remodeling. Circulation. 1996; 94:1941-1947. [PubMed: 8873672]

182. Farrow KN, Lakshminrusimha S, Reda WJ, Wedgwood S, Czech L, Gugino SF, Davis JM, Russell JA, Steinhorn RH. Superoxide dismutase restores eNOS expression and function in resistance pulmonary arteries from neonatal lambs with persistent pulmonary hypertension. Am J Physiol Lung Cell Mol Physiol. 2008; 295:L979-987. [PubMed: 18790993]

183. Wedgwood S, Steinhorn RH, Bunderson M, Wilham J, Lakshminrusimha S, Brennan LA, Black SM. Increased hydrogen peroxide downregulates soluble guanylate cyclase in the lungs of lambs with persistent pulmonary hypertension of the newborn. Am J Physiol Lung Cell Mol Physiol. 2005; 289:L660-666. [PubMed: 15937064]

184. Farrow KN, Groh BS, Schumacker PT, Lakshminrusimha S, Czech L, Gugino SF, Russell JA, Steinhorn RH. Hyperoxia increases phosphodiesterase 5 expression and activity in ovine fetal pulmonary artery smooth muscle cells. Circ Res. 2008; 102:226-233. [PubMed: 17991881] 
185. Wedgwood S, Black SM. Role of reactive oxygen species in vascular remodeling associated with pulmonary hypertension. Antioxidants \& redox signaling. 2003; 5:759-769. [PubMed: 14588149]

186. Nisbet RE, Bland JM, Kleinhenz DJ, Mitchell PO, Walp ER, Sutliff RL, Hart CM. Rosiglitazone attenuates chronic hypoxia-induced pulmonary hypertension in a mouse model. American journal of respiratory cell and molecular biology. 2010; 42:482-490. [PubMed: 19520921]

187. Wolin MS, Ahmad M, Gupte SA. The sources of oxidative stress in the vessel wall. Kidney Int. 2005; 67:1659-1661. [PubMed: 15840006]

188. Bedard K, Krause KH. The NOX family of ROS-generating NADPH oxidases: physiology and pathophysiology. Physiol Rev. 2007; 87:245-313. [PubMed: 17237347]

189. Amaya Y, Yamazaki K, Sato M, Noda K, Nishino T. Proteolytic conversion of xanthine dehydrogenase from the NAD-dependent type to the O2-dependent type. Amino acid sequence of rat liver xanthine dehydrogenase and identification of the cleavage sites of the enzyme protein during irreversible conversion by trypsin. J Biol Chem. 1990; 265:14170-14175. [PubMed: 2387845]

190. Waud WR, Rajagopalan KV. The mechanism of conversion of rat liver xanthine dehydrogenase from an NAD+-dependent form (type D) to an O2-dependent form (type O). Arch Biochem Biophys. 1976; 172:365-379. [PubMed: 176940]

191. Harris CM, Massey V. The oxidative half-reaction of xanthine dehydrogenase with NAD; reaction kinetics and steady-state mechanism. J Biol Chem. 1997; 272:28335-28341. [PubMed: 9353290]

192. Williamson JR, Chang K, Frangos M, Hasan KS, Ido Y, Kawamura T, Nyengaard JR, van den Enden M, Kilo C, Tilton RG. Hyperglycemic pseudohypoxia and diabetic complications. Diabetes. 1993; 42:801-813. [PubMed: 8495803]

193. Kelley EE, Khoo NK, Hundley NJ, Malik UZ, Freeman BA, Tarpey MM. Hydrogen peroxide is the major oxidant product of xanthine oxidase. Free Radic Biol Med. 2010; 48:493-498. [PubMed: 19941951]

194. Kelley EE, Hock T, Khoo NK, Richardson GR, Johnson KK, Powell PC, Giles GI, Agarwal A, Lancaster JR Jr, Tarpey MM. Moderate hypoxia induces xanthine oxidoreductase activity in arterial endothelial cells. Free Radic Biol Med. 2006; 40:952-959. [PubMed: 16540390]

195. Spiekermann S, Schenk K, Hoeper MM. Increased xanthine oxidase activity in idiopathic pulmonary arterial hypertension. Eur Respir J. 2009; 34:276. [PubMed: 19567609]

196. Lewis MS, Whatley RE, Cain P, McIntyre TM, Prescott SM, Zimmerman GA. Hydrogen peroxide stimulates the synthesis of platelet-activating factor by endothelium and induces endothelial cell-dependent neutrophil adhesion. J Clin Invest. 1988; 82:2045-2055. [PubMed: 3198764]

197. Terada LS, Guidot DM, Leff JA, Willingham IR, Hanley ME, Piermattei D, Repine JE. Hypoxia injures endothelial cells by increasing endogenous xanthine oxidase activity. Proc Natl Acad Sci U S A. 1992; 89:3362-3366. [PubMed: 1314387]

198. Cote CG, Yu FS, Zulueta JJ, Vosatka RJ, Hassoun PM. Regulation of intracellular xanthine oxidase by endothelial-derived nitric oxide. Am J Physiol. 1996; 271:L869-874. [PubMed: 8944732]

199. Houston M, Estevez A, Chumley P, Aslan M, Marklund S, Parks DA, Freeman BA. Binding of xanthine oxidase to vascular endothelium. Kinetic characterization and oxidative impairment of nitric oxide-dependent signaling. J Biol Chem. 1999; 274:4985-4994. [PubMed: 9988743]

200. Zulueta JJ, Sawhney R, Kayyali U, Fogel M, Donaldson C, Huang H, Lanzillo JJ, Hassoun PM. Modulation of inducible nitric oxide synthase by hypoxia in pulmonary artery endothelial cells. Am J Respir Cell Mol Biol. 2002; 26:22-30. [PubMed: 11751200]

201. Hinkle PC, Butow RA, Racker E, Chance B. Partial resolution of the enzymes catalyzing oxidative phosphorylation. XV. Reverse electron transfer in the flavin-cytochrome beta region of the respiratory chain of beef heart submitochondrial particles. J Biol Chem. 1967; 242:51695173. [PubMed: 4294331]

202. Boveris A, Chance B. The mitochondrial generation of hydrogen peroxide. General properties and effect of hyperbaric oxygen. Biochem J. 1973; 134:707-716. [PubMed: 4749271]

Free Radic Biol Med. Author manuscript; available in PMC 2013 December 09. 
203. Loschen G, Azzi A, Richter C, Flohe L. Superoxide radicals as precursors of mitochondrial hydrogen peroxide. FEBS Lett. 1974; 42:68-72. [PubMed: 4859511]

204. Boveris A, Cadenas E, Stoppani AO. Role of ubiquinone in the mitochondrial generation of hydrogen peroxide. Biochem J. 1976; 156:435-444. [PubMed: 182149]

205. Turrens JF, Boveris A. Generation of superoxide anion by the NADH dehydrogenase of bovine heart mitochondria. Biochem J. 1980; 191:421-427. [PubMed: 6263247]

206. Archer SL, Gomberg-Maitland M, Maitland ML, Rich S, Garcia JG, Weir EK. Mitochondrial metabolism, redox signaling, and fusion: a mitochondria-ROS-HIF-1alpha-Kv1.5 O2-sensing pathway at the intersection of pulmonary hypertension and cancer. Am J Physiol Heart Circ Physiol. 2008; 294:H570-578. [PubMed: 18083891]

207. Wolin MS. Reactive oxygen species and the control of vascular function. Am J Physiol Heart Circ Physiol. 2009; 296:H539-549. [PubMed: 19151250]

208. Hilenski LL, Clempus RE, Quinn MT, Lambeth JD, Griendling KK. Distinct subcellular localizations of Nox 1 and Nox4 in vascular smooth muscle cells. Arterioscler Thromb Vasc Biol. 2004; 24:677-683. [PubMed: 14670934]

209. Erusalimsky JD, Moncada S. Nitric oxide and mitochondrial signaling: from physiology to pathophysiology. Arterioscler Thromb Vasc Biol. 2007; 27:2524-2531. [PubMed: 17885213]

210. Biswas G, Anandatheerthavarada HK, Zaidi M, Avadhani NG. Mitochondria to nucleus stress signaling: a distinctive mechanism of NFkappaB/Rel activation through calcineurin-mediated inactivation of IkappaBbeta. J Cell Biol. 2003; 161:507-519. [PubMed: 12732617]

211. Palacios-Callender M, Quintero M, Hollis VS, Springett RJ, Moncada S. Endogenous NO regulates superoxide production at low oxygen concentrations by modifying the redox state of cytochrome c oxidase. Proc Natl Acad Sci U S A. 2004; 101:7630-7635. [PubMed: 15136725]

212. Cogolludo A, Frazziano G, Cobeno L, Moreno L, Lodi F, Villamor E, Tamargo J, Perez-Vizcaino F. Role of reactive oxygen species in Kv channel inhibition and vasoconstriction induced by TP receptor activation in rat pulmonary arteries. Ann N Y Acad Sci. 2006; 1091:41-51. [PubMed: 17341601]

213. Nozik-Grayck E, Suliman HB, Majka S, Albietz J, Van Rheen Z, Roush K, Stenmark KR. Lung EC-SOD overexpression attenuates hypoxic induction of Egr-1 and chronic hypoxic pulmonary vascular remodeling. Am J Physiol Lung Cell Mol Physiol. 2008; 295:L422-430. [PubMed: 18599502]

214. Burwell LS, Nadtochiy SM, Tompkins AJ, Young S, Brookes PS. Direct evidence for Snitrosation of mitochondrial complex I. Biochem J. 2006; 394:627-634. [PubMed: 16371007]

215. Dahm CC, Moore K, Murphy MP. Persistent S-nitrosation of complex I and other mitochondrial membrane proteins by S-nitrosothiols but not nitric oxide or peroxynitrite: implications for the interaction of nitric oxide with mitochondria. J Biol Chem. 2006; 281:10056-10065. [PubMed: 16481325]

216. Leach RM, Hill HM, Snetkov VA, Robertson TP, Ward JP. Divergent roles of glycolysis and the mitochondrial electron transport chain in hypoxic pulmonary vasoconstriction of the rat: identity of the hypoxic sensor. J Physiol. 2001; 536:211-224. [PubMed: 11579170]

217. Weissmann N, Ebert N, Ahrens M, Ghofrani HA, Schermuly RT, Hanze J, Fink L, Rose F, Conzen J, Seeger W, Grimminger F. Effects of mitochondrial inhibitors and uncouplers on hypoxic vasoconstriction in rabbit lungs. Am J Respir Cell Mol Biol. 2003; 29:721-732. [PubMed: 12791676]

218. Semenza GL. Oxygen-dependent regulation of mitochondrial respiration by hypoxia-inducible factor 1. Biochem J. 2007; 405:1-9. [PubMed: 17555402]

219. Chandel NS, McClintock DS, Feliciano CE, Wood TM, Melendez JA, Rodriguez AM, Schumacker PT. Reactive oxygen species generated at mitochondrial complex III stabilize hypoxia-inducible factor-1alpha during hypoxia: a mechanism of $\mathrm{O} 2$ sensing. J Biol Chem. 2000; 275:25130-25138. [PubMed: 10833514]

220. Guzy RD, Hoyos B, Robin E, Chen H, Liu L, Mansfield KD, Simon MC, Hammerling U, Schumacker PT. Mitochondrial complex III is required for hypoxia-induced ROS production and cellular oxygen sensing. Cell Metab. 2005; 1:401-408. [PubMed: 16054089] 
221. Delannoy E, Courtois A, Freund-Michel V, Leblais V, Marthan R, Muller B. Hypoxia-induced hyperreactivity of pulmonary arteries: role of cyclooxygenase-2, isoprostanes, and thromboxane receptors. Cardiovasc Res. 2010; 85:582-592. [PubMed: 19710084]

222. Archer SL, Marsboom G, Kim GH, Zhang HJ, Toth PT, Svensson EC, Dyck JR, GombergMaitland M, Thebaud B, Husain AN, Cipriani N, Rehman J. Epigenetic attenuation of mitochondrial superoxide dismutase 2 in pulmonary arterial hypertension: a basis for excessive cell proliferation and a new therapeutic target. Circulation. 2010; 121:2661-2671. [PubMed: 20529999]

223. McMurtry MS, Bonnet S, Wu X, Dyck JR, Haromy A, Hashimoto K, Michelakis ED. Dichloroacetate prevents and reverses pulmonary hypertension by inducing pulmonary artery smooth muscle cell apoptosis. Circ Res. 2004; 95:830-840. [PubMed: 15375007]

224. Bonnet S, Michelakis ED, Porter CJ, Andrade-Navarro MA, Thebaud B, Haromy A, Harry G, Moudgil R, McMurtry MS, Weir EK, Archer SL. An abnormal mitochondrial-hypoxia inducible factor-1alpha-Kv channel pathway disrupts oxygen sensing and triggers pulmonary arterial hypertension in fawn hooded rats: similarities to human pulmonary arterial hypertension. Circulation. 2006; 113:2630-2641. [PubMed: 16735674]

225. Bonnet S, Archer SL. Potassium channel diversity in the pulmonary arteries and pulmonary veins: implications for regulation of the pulmonary vasculature in health and during pulmonary hypertension. Pharmacology \& therapeutics. 2007; 115:56-69. [PubMed: 17583356]

226. Michelakis ED, Hampl V, Nsair A, Wu X, Harry G, Haromy A, Gurtu R, Archer SL. Diversity in mitochondrial function explains differences in vascular oxygen sensing. Circ Res. 2002; 90:1307-1315. [PubMed: 12089069]

227. Dohi T, Beltrami E, Wall NR, Plescia J, Altieri DC. Mitochondrial survivin inhibits apoptosis and promotes tumorigenesis. J Clin Invest. 2004; 114:1117-1127. [PubMed: 15489959]

228. McMurtry MS, Archer SL, Altieri DC, Bonnet S, Haromy A, Harry G, Puttagunta L, Michelakis ED. Gene therapy targeting survivin selectively induces pulmonary vascular apoptosis and reverses pulmonary arterial hypertension. J Clin Invest. 2005; 115:1479-1491. [PubMed: 15931388]

229. Fijalkowska I, Xu W, Comhair SA, Janocha AJ, Mavrakis LA, Krishnamachary B, Zhen L, Mao T, Richter A, Erzurum SC, Tuder RM. Hypoxia inducible-factorlalpha regulates the metabolic shift of pulmonary hypertensive endothelial cells. Am J Pathol. 2010; 176:1130-1138. [PubMed: 20110409]

230. Xu W, Koeck T, Lara AR, Neumann D, DiFilippo FP, Koo M, Janocha AJ, Masri FA, Arroliga AC, Jennings C, Dweik RA, Tuder RM, Stuehr DJ, Erzurum SC. Alterations of cellular bioenergetics in pulmonary artery endothelial cells. Proc Natl Acad Sci U S A. 2007; 104:13421347. [PubMed: 17227868]

231. Kim JW, Dang CV. Multifaceted roles of glycolytic enzymes. Trends Biochem Sci. 2005; 30:142-150. [PubMed: 15752986]

232. Bonnet S, Archer SL, Allalunis-Turner J, Haromy A, Beaulieu C, Thompson R, Lee CT, Lopaschuk GD, Puttagunta L, Harry G, Hashimoto K, Porter CJ, Andrade MA, Thebaud B, Michelakis ED. A mitochondria-K+ channel axis is suppressed in cancer and its normalization promotes apoptosis and inhibits cancer growth. Cancer Cell. 2007; 11:37-51. [PubMed: 17222789]

233. Girgis RE, Li D, Zhan X, Garcia JG, Tuder RM, Hassoun PM, Johns RA. Attenuation of chronic hypoxic pulmonary hypertension by simvastatin. Am J Physiol Heart Circ Physiol. 2003; 285:H938-945. [PubMed: 12750068]

234. Murata T, Kinoshita K, Hori M, Kuwahara M, Tsubone H, Karaki H, Ozaki H. Statin protects endothelial nitric oxide synthase activity in hypoxia-induced pulmonary hypertension. Arterioscler Thromb Vasc Biol. 2005; 25:2335-2342. [PubMed: 16166567]

235. Hemnes AR, Zaiman A, Champion HC. PDE5A inhibition attenuates bleomycin-induced pulmonary fibrosis and pulmonary hypertension through inhibition of ROS generation and RhoA/Rho kinase activation. Am J Physiol Lung Cell Mol Physiol. 2008; 294:L24-33. [PubMed: 17965319]

236. Kentera D, Susic D, Veljkovic V, Tucakovic G, Koko V. Pulmonary artery pressure in rats with hereditary platelet function defect. Respiration. 1988; 54:110-114. [PubMed: 3231895] 
237. Rabinovitch M. PPARgamma and the pathobiology of pulmonary arterial hypertension. Adv Exp Med Biol. 2010; 661:447-458. [PubMed: 20204748]

238. Sutendra G, Bonnet S, Rochefort G, Haromy A, Folmes KD, Lopaschuk GD, Dyck JR, Michelakis ED. Fatty acid oxidation and malonyl-CoA decarboxylase in the vascular remodeling of pulmonary hypertension. Sci Transl Med. 2010; 2:44ra58.

239. Lu X, Murphy TC, Nanes MS, Hart CM. PPAR \{gamma $\}$ regulates hypoxia-induced Nox4 expression in human pulmonary artery smooth muscle cells through NF-\{kappa $\}$ B. Am J Physiol Lung Cell Mol Physiol. 2010; 299:L559-566. [PubMed: 20622120]

240. Kim EK, Lee JH, Oh YM, Lee YS, Lee SD. Rosiglitazone attenuates hypoxia-induced pulmonary arterial hypertension in rats. Respirology. 2010; 15:659-668. [PubMed: 20546541]

241. Sutliff RL, Kang BY, Hart CM. PPARgamma as a potential therapeutic target in pulmonary hypertension. Ther Adv Respir Dis. 2010; 4:143-160. [PubMed: 20530063]

242. Hansmann G, Zamanian RT. PPARgamma activation: a potential treatment for pulmonary hypertension. Sci Transl Med. 2009; 1:12ps14.

243. Li M, Li Z, Sun X, Yang L, Fang P, Liu Y, Li W, Xu J, Lu J, Xie M, Zhang D. Heme oxygenase-1/p21WAF1 mediates peroxisome proliferator-activated receptor-gamma signaling inhibition of proliferation of rat pulmonary artery smooth muscle cells. FEBS J. 2010; 277:15431550. [PubMed: 20163460]

244. Tian J, Smith A, Nechtman J, Podolsky R, Aggarwal S, Snead C, Kumar S, Elgaish M, Oishi P, Goerlach A, Fratz S, Hess J, Catravas JD, Verin AD, Fineman JR, She JX, Black SM. Effect of PPARgamma inhibition on pulmonary endothelial cell gene expression: gene profiling in pulmonary hypertension. Physiol Genomics. 2009; 40:48-60. [PubMed: 19825830]

245. Stasch JP, Pacher P, Evgenov OV. Soluble guanylate cyclase as an emerging therapeutic target in cardiopulmonary disease. Circulation. 2011; 123:2263-2273. [PubMed: 21606405]

246. Gladwin MT, SA, Kim-Shapiro DB, Patel RP, Hogg N, Shiva S, Cannon RO 3rd, Kelm M, Wink DA, Espey MG, Oldfield EH, Pluta RM, Freeman BA, Lancaster JR Jr, Feelisch M, Lundberg JO. The emerging biology of the nitrite anion. Nat Chem Biol. 2005; 1:308-314. [PubMed: 16408064]

247. Cheng JW. Ambrisentan for the management of pulmonary arterial hypertension. Clin Ther. 2008; 30:825-833. [PubMed: 18555930] 


\section{Highlights}

- PAH is characterized by endothelial dysfunction and enhanced cellular proliferation

- Worsening in patients with PAH is related to development of right heart failure

- Many reactive oxygen species and NO signaling pathways are disrupted in PAH

- Novel therapeutic strategies use nitrite and recoupling of eNOS to enhance NO

- Other strategies include inhibition of Nox, xanthine oxidase, and scavenging $\mathrm{O}_{2}^{-}$ 


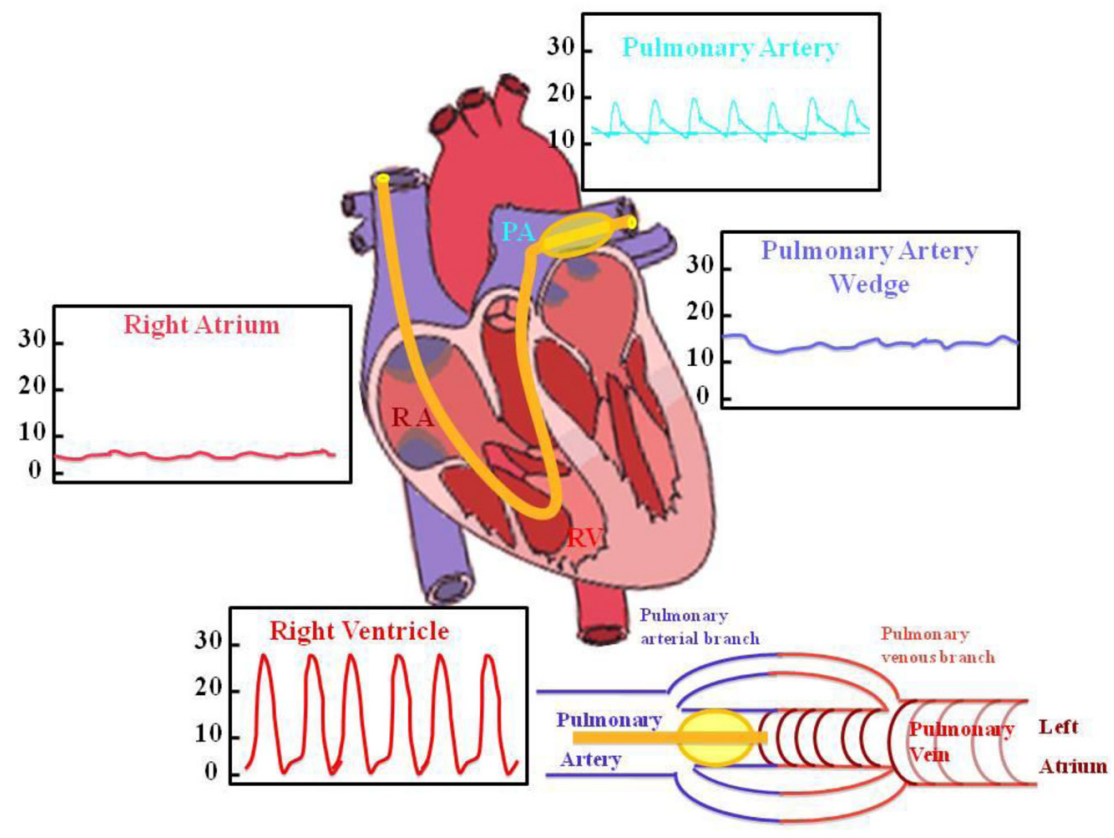

Figure 1.

Swan-Ganz Standard Thermodilution Pulmonary Artery Catheter permits measurement of right atrium, right ventricle, pulmonary artery and pulmonary artery wedge pressure (also called pulmonary artery occlusion pressure). To measure the pressure in vivo a balloon is inflated in the tip of this flow-directed catheter. The balloon is inflated to occlude a small distal branch of the pulmonary artery, and then the pressure is measured during occlusion and captures the reflected pressure coming from the left atrium. 

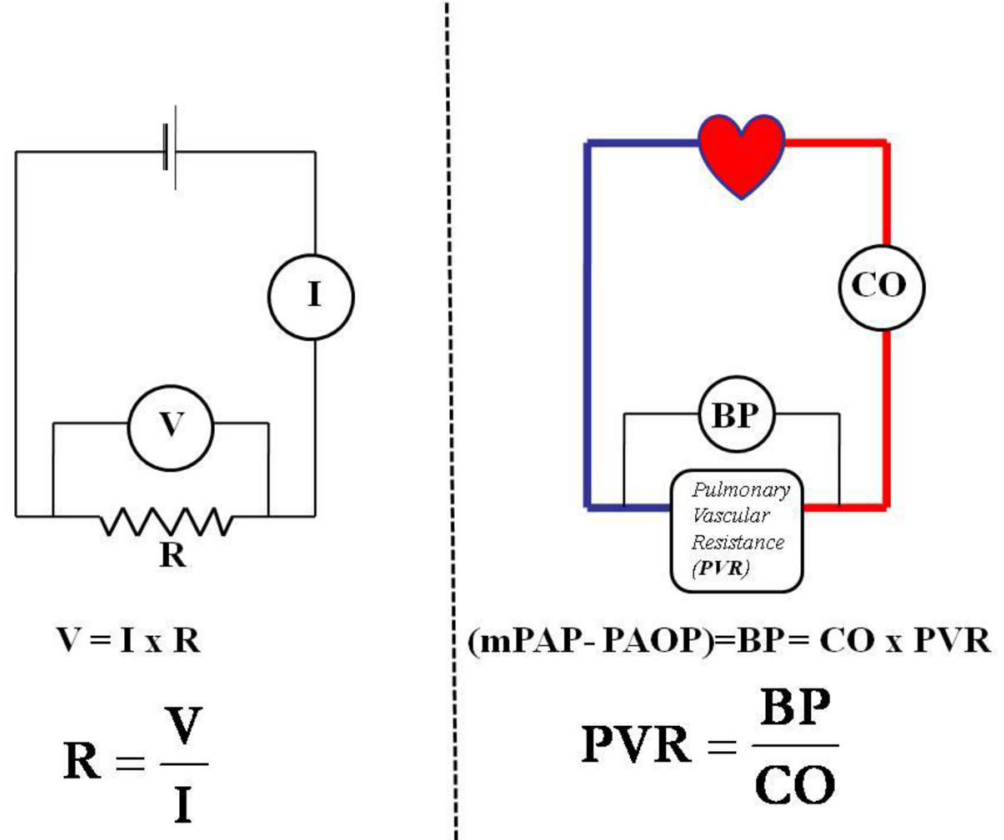

Figure 2.

The electrical principles found in Ohm's law are applicable to the pulmonary circulation. Electrically, with a given current flow (I), the voltage $(\mathrm{V})$ that is generated across the resistance is given by $\mathrm{I} x \mathrm{R}$. In the case of the pulmonary circulation, for any given blood flow $(\mathrm{CO})$, the blood pressure $(\mathrm{BP})$ that will be generated by this flow through the pulmonary vascular resistance $(\mathrm{PVR})$ is given by the same relation: $\mathrm{BP}=\mathrm{CO} \times \mathrm{PVR}$. $\mathrm{BP}$ is defined by the difference between mean pulmonary artery pressure (mPAP) and the pulmonary artery occlusion pressure (PAOP). 


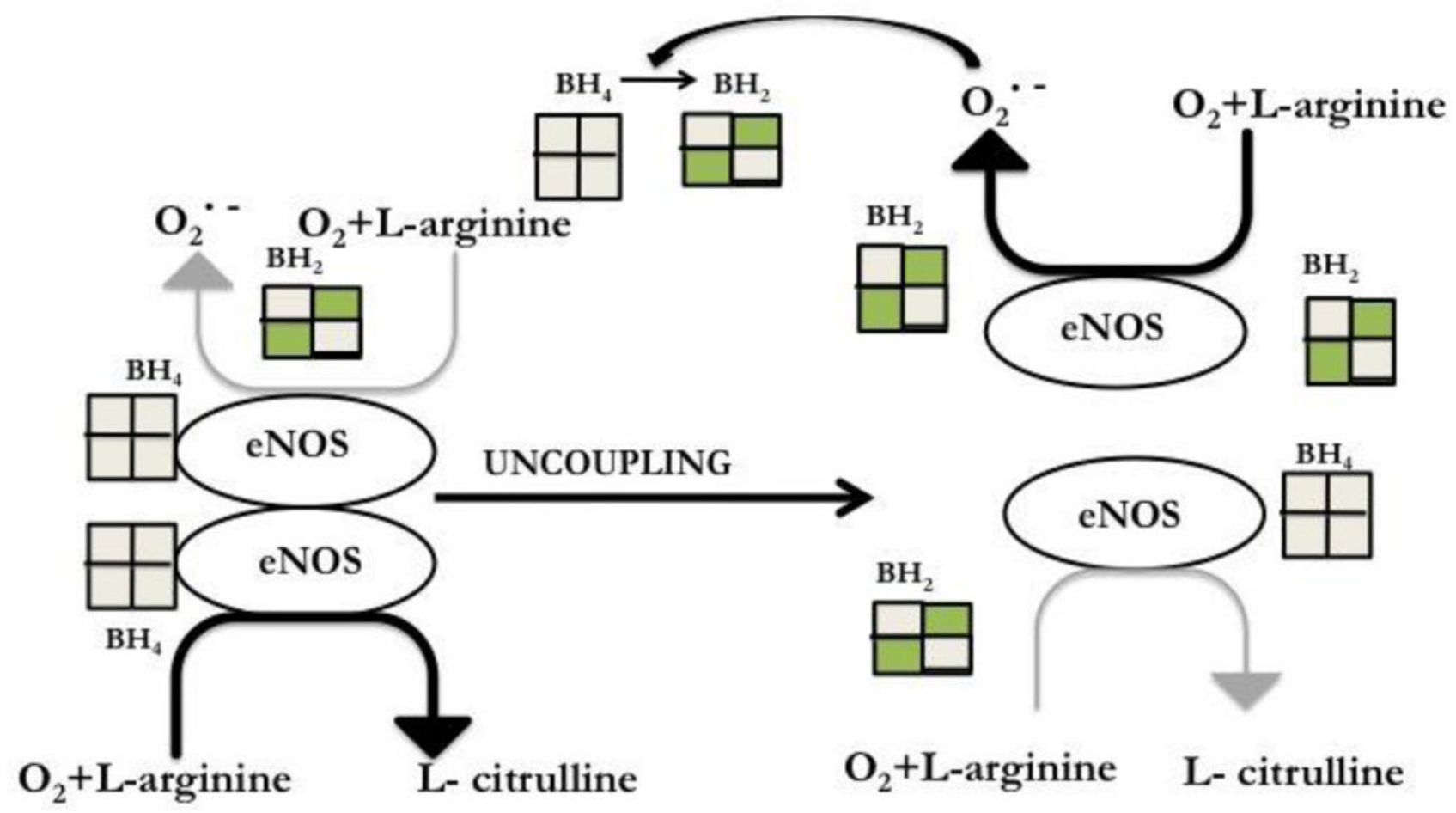

Figure 3.

The uncoupling of eNOS is a dysfunctional state of the enzyme. In the presence of sufficient L-arginine and $\mathrm{BH}_{4}$, eNOS produces $\mathrm{NO}$ (thick arrow) and limited superoxide (thin arrow). When $\mathrm{BH}_{4}$ is oxidized to $\mathrm{BH}_{2}$, uncoupled electrons transferring from the NOS reductase domain to the oxygenase domain are diverted to oxygen (thick arrow) rather than $\mathrm{L}$-arginine (thin arrow). 


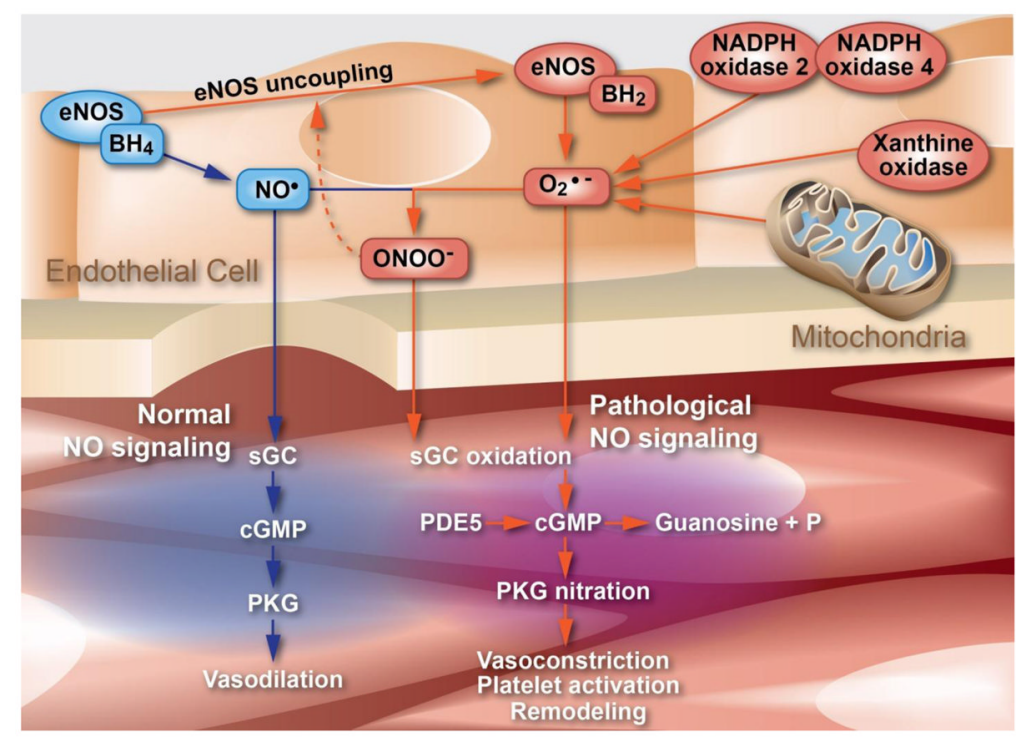

Figure 4.

A schematic representation of the possible interplay of eNOS uncoupling, reactive oxygen species (ROS) and soluble guanylate cyclase (sGC) in the pathogenesis of pulmonary arterial hypertension. Adapted with permission from [245]. 


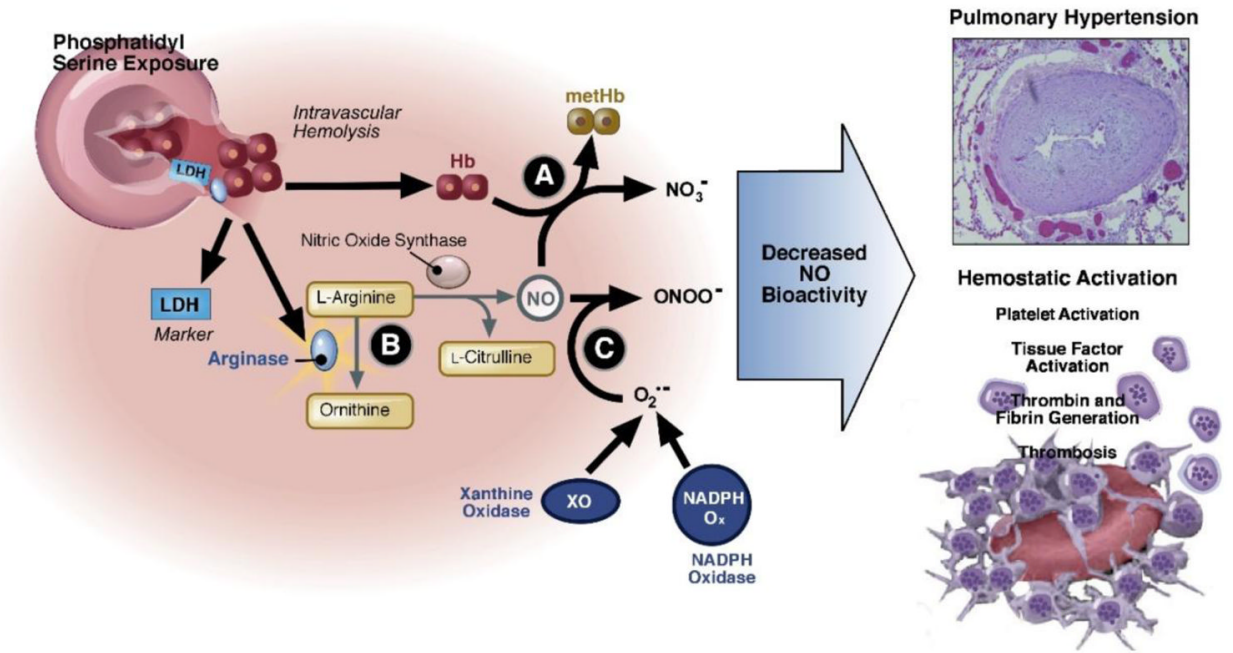

Figure 5.

Representation of the pathogenesis of hemolysis-associated pulmonary hypertension. Intravascular hemolysis releases red blood cell hemoglobin into plasma, which reacts with NO. Furthermore, hemolysis releases arginase 1, which reduces L-arginine availability to synthesize NO. Xanthine oxidase and NADPH oxidase are upregulated and produce superoxide, which also inhibits NO. Reduced NO bioavailability and bioactivity promotes vasoconstriction, the development of pulmonary hypertension, and activation platelets and the hemostatic system. The pulmonary vascular lesion shown is taken from an autopsy specimen from a 35 year old male patient with sickle cell disease who died of sudden death, and shows severe concentric intimal and smooth muscle hyperplasia characteristic of advanced pulmonary hypertension. 

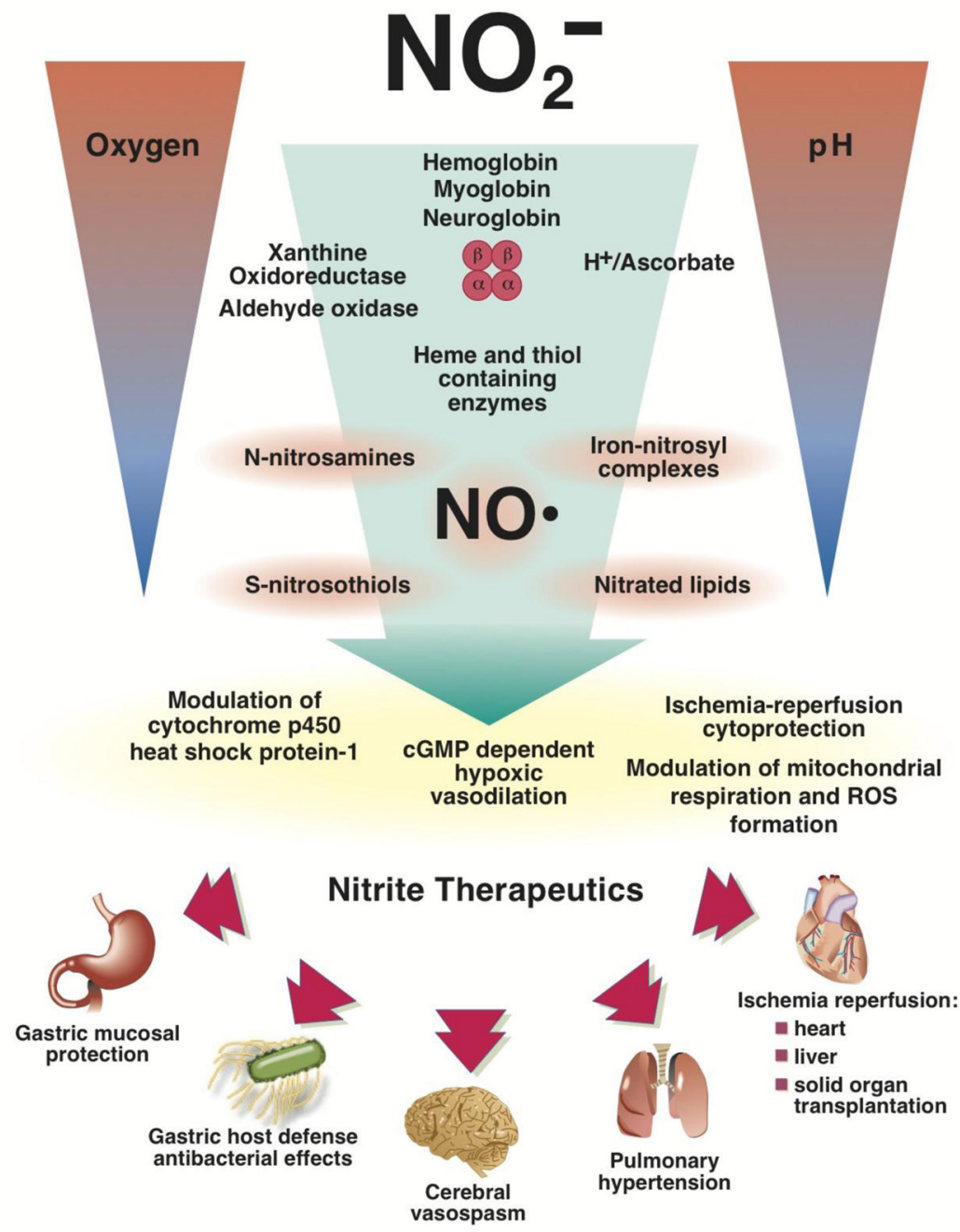

Figure 6.

A schematic representation of the process and consequences of nitrite reduction. Nitrite can be metabolized to form NO by various enzymatic and non-enzymatic pathways as oxygen tension and $\mathrm{pH}$ decrease. The formation of $\mathrm{NO}$ and $\mathrm{NO}$ related signaling molecules drives hypoxic signaling and protective effects in a number of disease models. The figure is modified and reproduced with permission from [246]. 


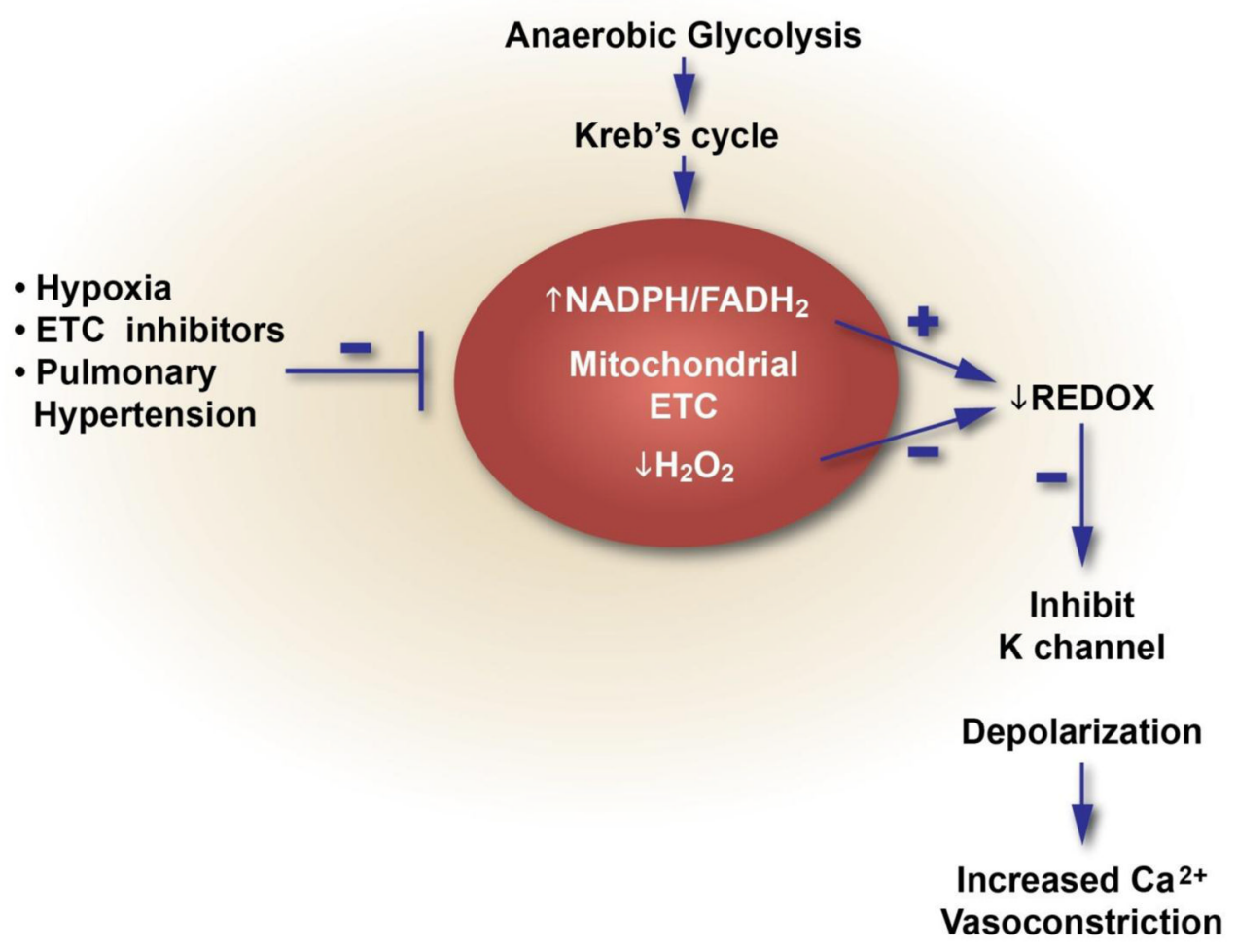

Figure 7.

Schematic showing how changes in the mitochondria cause PAH based on a cancer analogy theory. In this theory, changes in the mitochondria cause a decrease in the production of mitochondria-derived reactive oxygen species, inhibiting redox-sensitive potassium channels in the plasma membrane, causing depolarization, opening of voltage -gated $\mathrm{Ca}^{2+}$ channels, influx of $\mathrm{Ca}^{2+}$ and constriction. 
Table 1

Clinical classification of pulmonary hypertension from Dana Point, 2008.

\begin{tabular}{|c|c|c|}
\hline Class & Name & Categories \\
\hline I & $\begin{array}{l}\text { Pulmonary arterial hypertension } \\
\text { (PAH) }\end{array}$ & $\begin{array}{ll}\text { Subdivided into: } \\
\text { - } & \text { Idiopathic } \\
\text { - } & \text { Familial or heritable } \\
\text { - } & \text { Induced by drugs and toxins } \\
\text { - } & \text { Associated } \\
\text { - } & \text { Persistent pulmonary hypertension of the newborn } \\
\text { - } & \text { PAH secondary to veno-occlusive disease and/or pulmonary capillary } \\
\text { hemangiomatosis }\end{array}$ \\
\hline II & $\begin{array}{l}\text { Pulmonary hypertension owing to } \\
\text { left-heart disease }\end{array}$ & $\begin{array}{ll}\text { - } & \text { Systolic dysfunction } \\
\text { - } & \text { Diastolic dysfunction } \\
\text { - } & \text { Valvular disease }\end{array}$ \\
\hline III & $\begin{array}{l}\text { Pulmonary hypertension owing to } \\
\text { lung disease and/or hypoxia }\end{array}$ & $\begin{array}{ll}\text { - } & \text { Chronic obstructive pulmonary disease } \\
\text { - } & \text { Interstitial lung disease } \\
\text { - } & \text { Other pulmonary diseases with mixed restrictive and obstructive pattern } \\
\text { - } & \text { Sleep-disordered breathing } \\
\text { - } & \text { Alveolar hypoventilation disorders } \\
\text { - } & \text { Chronic exposure to high altitude } \\
\text { - } & \text { Developmental abnormalities }\end{array}$ \\
\hline IV & $\begin{array}{c}\text { Chronic thromboembolic pulmonary } \\
\text { hypertension }\end{array}$ & \\
\hline $\mathbf{v}$ & $\begin{array}{l}\text { Pulmonary hypertension with unclear } \\
\text { multifactorial mechanisms } \\
\text { (Miscellaneous conditions) }\end{array}$ & $\begin{array}{ll}\text { - } & \text { Hematologic disorders } \\
\text { - } & \text { Systemic disorders } \\
\text { - } & \text { Metabolic disorders } \\
\text { - } & \begin{array}{l}\text { Others: Tumoral obstruction, fibrosing mediastinitis, chronic renal failure on } \\
\text { dialysis }\end{array}\end{array}$ \\
\hline
\end{tabular}


Table 2

Approved medications for the therapy of PAH.

\begin{tabular}{|c|c|}
\hline Drug & Characteristics \\
\hline Calcium-channel blocker & $\begin{array}{l}\text { Disrupt the movement of calcium through the calcium channels. Examples of this } \\
\text { group are nifedipine, dilitiazem and amlodipine. }\end{array}$ \\
\hline Prostacyclin and its derivatives & $\begin{array}{l}\text { Effects on the pulmonary vasculature, including inhibition of smooth muscle cell } \\
\text { constriction and proliferation, as well as platelet aggregation. Examples of this } \\
\text { group are epoprostenol, treprostinil and iloprost. }\end{array}$ \\
\hline $\begin{array}{l}\text { Cyclic guanosine monophosphate } \\
\text { (cGMP)-binding cGMP-specific } \\
\text { phosphodiesterase inhibitors }\end{array}$ & $\begin{array}{l}\text { - Sildenafil (phosphodiesterase type } 5 \text { inhibitor): Recommended for patients with } \\
\text { advanced PAH. } \\
\text { Tadalafil: The first once-daily phosphodiesterase type } 5 \text { inhibitor has shown } \\
\text { favorable results. }\end{array}$ \\
\hline Endothelin receptor antagonists & $\begin{array}{l}\text { - } \quad \text { Bosentan: Recommended for patients with advanced } \mathrm{PAH} . \\
\text { - } \\
\text { - } \\
\text { Ambrisentant Selective } \mathrm{ET}_{\mathrm{A}} \text { receptor. } \\
\text { clinical worsening [247]. }\end{array}$ \\
\hline Combination therapy & - Option for patients not responding to the initial therapy. \\
\hline
\end{tabular}

